\title{
FOREST HEALTH IN NORTH AMERICA: SOME PERSPECTIVES ON ACTUAL AND POTENTIAL ROLES OF CLIMATE AND AIR POLLUTION
}

\section{S. MCLAUGHLIN and K. PERCY?}

'Environmental Sciences Division, Oak Ridge National Laboratory, PO Box 2008, MS 6422, Oak Ridge, TN, 37830, USA; 'Natural Resources Canada, Canadian Forest Service, Atlantic Forestry Centre, Fredericton, N.B., E3B 5P7, Canada

\author{
(Received 25 September 1998; accepted 25February 1999)
}

\begin{abstract}
The perceived health of forest coosystems over large temporal and spatial scales can be strongly influenced by the frames of reference chosen to evaluate both forest condition and the functional integrity of sustaining forest processes. North American forests arc diverse in range, species composition, past disturbance history, and current maragement practices. Therefore the implications of changes in environmental stress from atmospheric pollution and/or global climate change on health of these forests will vary widely across the landscape. Forest health surveys that focus on the average forest condition may do a credible job of representing the near -term trends in economic value while failing to detect fundamental changes in the processes by which these values are sustained over the longer term. Indications of increased levels of environmental stress on forest growth and nutrient cycles are currently apparent in several forest types in North America Measurements of forest ecophysiological responses to air pollutants in integrated case studies with four forest types (southern pine, western pine, high elevation red spruce, and northeastern hardwoods) indicate that ambient levels of ozone and/or acidic deposition can alter basic processes of water, carbon, and nutrient allocation by forest trees. These changes then provide a mechanistic basis for pollutant stress to enhance a wider range ofnatural stresses that also affect and are affected by these resources. Future climatic changes may ameliorate $\left(+\mathbf{C O}_{2}\right)$ or exacerbate $(+$ temperature, $+\mathrm{W}-\mathrm{B})$ these effects. Current projections of forest responses to global climate change do not consider important physiological changes induced by air pollutants that may amplify climatic stresses. These include reduced rooting mass, depth, and function, increased respiration, and reduced water use efficiency. Monitoring and understanding the relative roles of natural and anthropogenic stress in influencing future forest health will require programs that are structured to evaluate responses at appropriate frequencies across gradients in both forest resources and the stresses that influence them Such programs must also be accompanied by supplemental pr- -oriented and pattern -oriented investigations that more thoroughly test cause and effect relationships among stresses and responses of both forests and the biogeochemical cycles that sustain them.
\end{abstract}

Key Words: air quality, physiology, growth, biotic and abiotic interactions

\section{Introduction}

The forests of North America are immense in both their geographical range and ecological diversity. The $326 \mathrm{M}$ ha of forested land in the USA (Powell et al., 1992) and $417 \mathrm{M}$ ha in Canada (NRCAN, 1998) are also a highly valuable economic resource for which maintenance of long term productivity is a very high priority. Both actual and perceived potential responses of North American forests to atmospheric pollution during recent decades have figured strongly in policy decisions on air quality regulation that have had significant economic and ecological implications for the region. In the next century, if current increases in atmospheric $\mathrm{CO}_{2}$ continue and projected changes in both temperature and atmospheric deposition of nitrogen $(\mathbb{N})$ occur, changes in forest productivity and

- function will be of interest not only in terms of shifts in patterns of production, but also from the perspective of the role of forests as sinks or sources for greenhouse gases (Norby, 1998). IPCC (1998) predictions for the effects of Global Climate Change on forest health include both increased growth and range of some forests, but also an increased frequency of declining health in others in response to increased biotic and abiotic stresses associated

The authors wish to express their sincere appreciation to Dr. R. Vet, Atmospheric Environment Service, Environment Canada, Downsview. Ontario, and to Dr. T. Dasn, Environment Protection Service, Environment Canada, Ottawa, Ontario, for calculation and mapping of $\mathbf{S O}_{4}, \mathrm{NO}_{3} \mathrm{H}$ ion depositions and cumulative $\mathbf{O}_{3}$ sums.

Water, Air, and Soil Pollution 116: 1.51-197, 1999.

() 1999 Kluwer Academic Publishers. Printed in the Netherlands. 
with climatic warming. Evaluating forest health and forest biogeochemical functions in this more complex future environment will increasingly challenge forest scientists to measure and understand the basic processes underlying forest growth and longer term ecological health.

Perspectives on forest health and current risks posed by chemical and physical climate change differ widely within the forest community (Jenkins, 1997). These differences often stem from varying perspectives of forest values and times scales over which change is evaluated. Kolb et al. (1994) differentiated between the utilitarian view of forest health, which stresses timber production as the primary endpoint and the ecosystem perspective, which views forest health in terms of measures of longer term forest function. The latter include properties such as resilience, diversity, and the flow of carbon, water, and nutrient resources required for tree resistence to natural stresses and maintenance of biogeochemical cycles. Assessment of forest health, in fact, has many dimensions (Innes, 1993), and at the time of our writing, there exists no universally-accepted definition of a healthy forest. O'Laughlin et al. (1994) have defined forest health as ". . . a condition of forest ecosystems that sustains their complexity while providing for human needs". This definition stresses the utilitarian endpoint, which is defined in anthropocentric terms. We focus here on a more fundamental definition - A capacity to supply and allocate water, nutrients, and energy in ways that increase or maintain productivity while maintaining resistance to biotic and abioticstresses. We, therefore, define less healthy forests as ones in which trees lose productive capacity and/or become more sensitive to environmental stresses. We should note here that unhealthy trees and stands occur naturally as a part of successional processes by which a balance between forest production, site resources, and climate are attained. In this capacity, for example, grazing insects can serve an important role in establishing a balance in nutrient flow to foliage from nutrient deficient soils (Matson and Addy, 1975). The patterns by which such changes occur however are typically spatially and temporally heterogeneous as are the localized biotic and abiotic factors that influence them.

Ecosystem response to environmental stresses, including air pollutants, is a complex, hierarchical process occurring over time scales ranging from minutes (leaf) to decades (stand). However, air pollution stresses are somewhat distinct from many other forms of environmental stress because of their regional patterns and temporal consistency with changes in air quality. Stress responses begin with sensitive individuals proceeding from branch, to tree, and then stand and ecosystem levels (Hinckley et al., 1992) Underlying these response are process-level changes in uptake and allocation of carbon, water, and nutrient resources. We focus here on linkages between process level changes and ecosystem responses because this approach offers the best chance to understand the individual and interactive effects that will ultimately determine the utilitarian values of forest systems.

This paper summarizes recent advancesin understanding of process level effects of regional air pollution on four forest types for which recent syntheses are available. These include the southeastern pine forest, eastern spruce/fir ecosystem, northeastern hardwoods, and western pine forests in Southern California (Figure 1). Our objective is to evaluate how increased understanding of forest process effects can be integrated into regional monitoring and analysis of forest health in relation to both air pollution and its interactions with other biotic and abiotic stresses that affect forests. We have emphasized primarily ozone and acidic deposition ( $\mathrm{N}$ and $\mathrm{S}$ ), the pollutants with the greatest potential regional impact on forests in the U.S. and Canada. Measured and potential impacts have been evaluated from the following perspectives: 


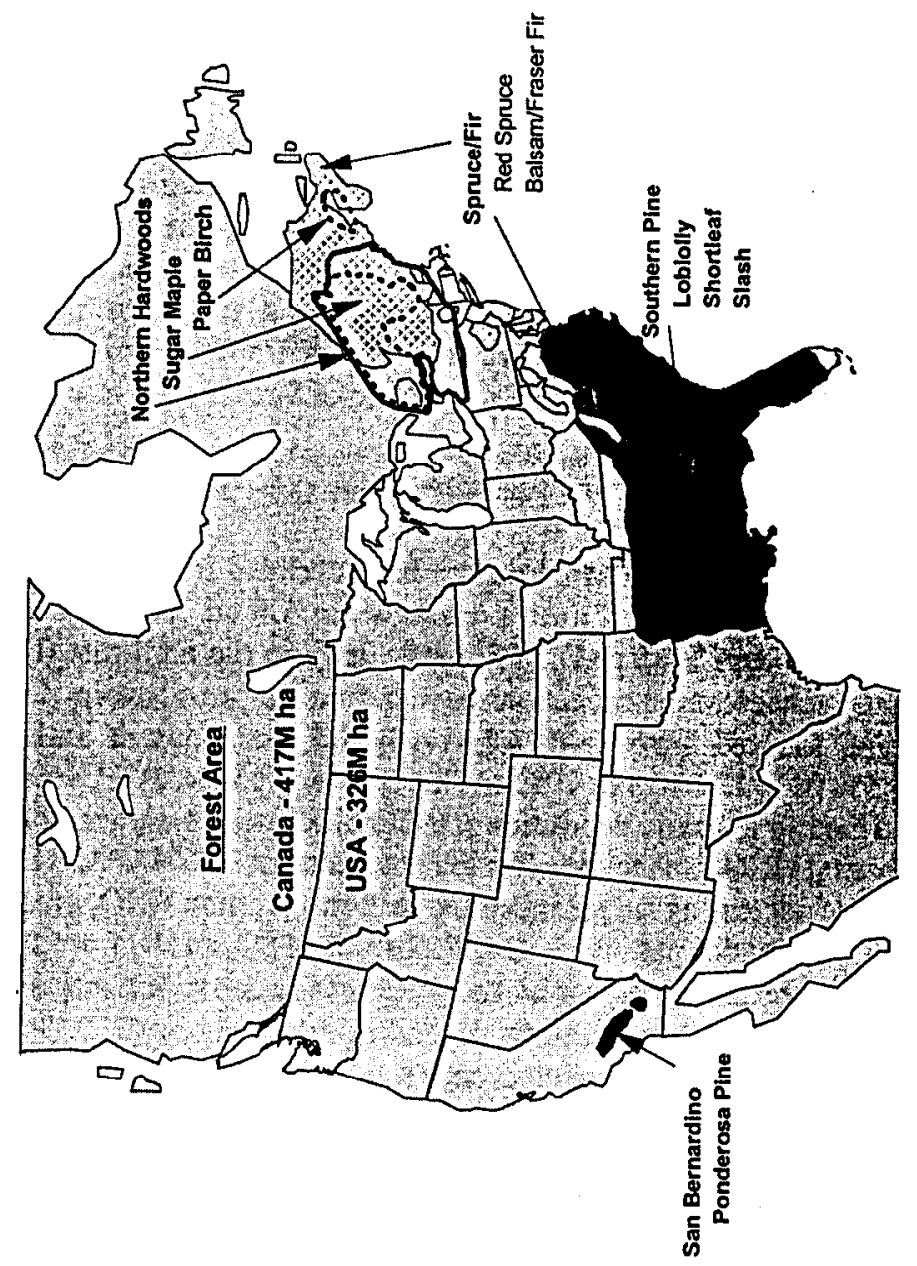

Figure 1. Multidisciplinary research from case studies in southwestem pine, southeastem pine, easternspruce-fir, and northeastern hardwood forest types was examined to evaluate process level responses to ambient levels of air pollutants in four regional forest types. 
(1). Monitoring air quality and forest health in North America.

(2). Evidence of changes in allocation patterns of carbon, water, and nutrients related to ozone or acidic deposition within the four "case-study" forests.

(3). Implications of process-level changes on whole-tree function and biogeochemical processes in current and future climate regimes.

(4). Recommendations for incorporating process-based ecosystem perspectives into regional monitoring of forest health.

\section{Regional Air Quality in North America}

Recent syntheses in both the United States (NAPAP, 1998) and Canada (EC, 1997) demonstrate clear qualitative relationshipsbetween spatial patterns of acidic gas emissions and measured air concentrations and wet deposition patterns that were already evident by the 1990 assessments (RMCC,1990). Here, we concentrate on acidic deposition and $\mathbf{O}_{\mathbf{3}}$ as they affect our forests regionally, while recognizing that their co-occurrence and interactions with other abiotic (e.g., climate extremes, UV-B, toxics) and biotic stressors ultimately determines the direction and magnitude of forest health responses.

\subsection{ACIDIC DEPOSITION}

Emissions of $\mathrm{SO}_{2}$ in eastern North America have declined from over $20 \mathrm{M} \mathrm{t}$ in 1980 to under $17 \mathrm{M}$ t in 1993 (EC, 1997). As a consequence, US air concentrations of $\mathbf{S O}_{2}$ have decreased 37\% between 1985 and 1995, particularly in the northeast (NAPAP, 1998). Particulate $\mathrm{SO}_{4}$ concentration reductions have been widespread, except at several mid- to high-elevation, forested areas (NAPAP, 1998). US emissions of anthropogenic NO, decreased $6.5 \%$ from $23.3 \mathrm{M} \mathrm{t}$ in 1980 to $21.8 \mathrm{Mt}$ in 1995 (NAPAP, 1998). Trends in N species contributing to acidic deposition $\left(\mathbf{H N O}_{3}, \mathrm{NO}\right.$,) were more variable than for $\mathbf{S O}_{\mathbf{2}}$. While decreasing $\mathrm{HNO}_{3}$ was reported in the northeastern US (NAPAP, 1998), Canadian data showed and increasing frequency of higher concentration $\mathrm{HNO}_{3}$ events (EC, 1997).

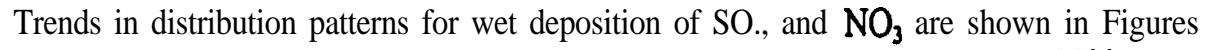
2 and 3. It should be noted that additional inputs of dry deposition may add 8-37\% more $\mathrm{S}$ and $\mathbf{1 5 - 6 5 \%}$ more $\mathrm{N}$ to these numbers depending on the region (EC, 1997). Contrasts in wet $\mathrm{SO}$, and NO, deposition patterns reveal strong reductions for $\mathrm{S}$ in the area enclosed by the IO-30 kg ha-' $\mathrm{yr}^{-1}$ isopleths. Also evident was the disappearance of the $30 \mathrm{~kg} \mathrm{ha}^{-1} \mathrm{yr}^{-1}$ area in Canada, and its considerable reduction in the US (Figures 2a,b) (EC, 1997). In contrast, $\mathrm{NO}_{3}$ wet deposition did not change dramatically. Areas receiving $5-25 \mathrm{~kg} \mathrm{NO}_{3} \mathbf{h a}^{-1} \mathbf{y r}^{-1}$ expanded marginally (Figures 3 a,b) (EC, 1997). When integrated, areas in Canada within the $20 \mathrm{~kg} \mathrm{ha}^{-1} \mathrm{yr}^{-1}$ wet SO, isopleth decreased $44 \%$ from 629,000 ha in $1980-83$ to 340,000 ha in 1990-93 (EC, 1997).

Hall et al. (1997) recommended a critical threshold of $12 \mathrm{~kg} \mathrm{SO}$, ha-' $\mathrm{yr}^{-1}$ for wet deposition to poorly buffered Canadian soils. In the context of forest/lake hydrological process linkages, current wet SO., deposition exceeds critical loads at all eastern Canadian lake clusters by $7 \cdot \cdot 12 \mathrm{~kg} \mathrm{ha}^{-1} \mathbf{y r}^{-1}$ and is expected to exceed them by about 6 to $10 \mathrm{~kg} \mathrm{ha}^{-1} \mathbf{y r}^{-1}$ after all emission controls required by the Canada/US Air Quality Agreement are fully implemented (Jeffries, 1997). 


\section{4- Year Mean $\mathrm{XSO}_{4}=$ Patterns}

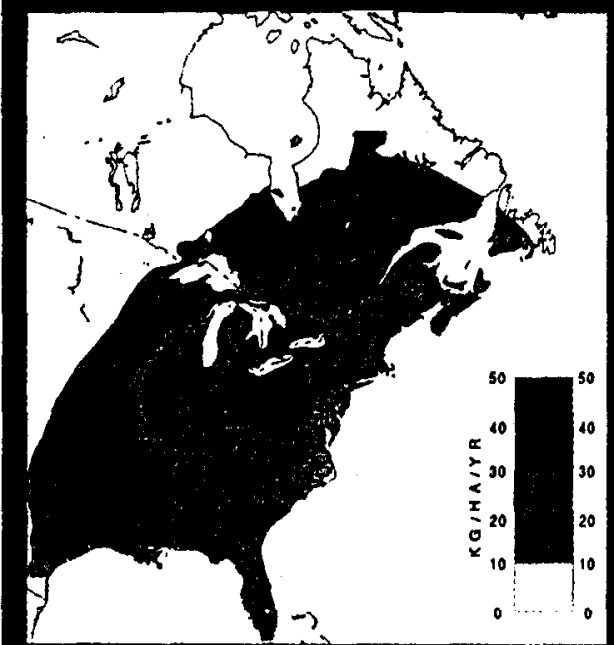

$1980-1983$

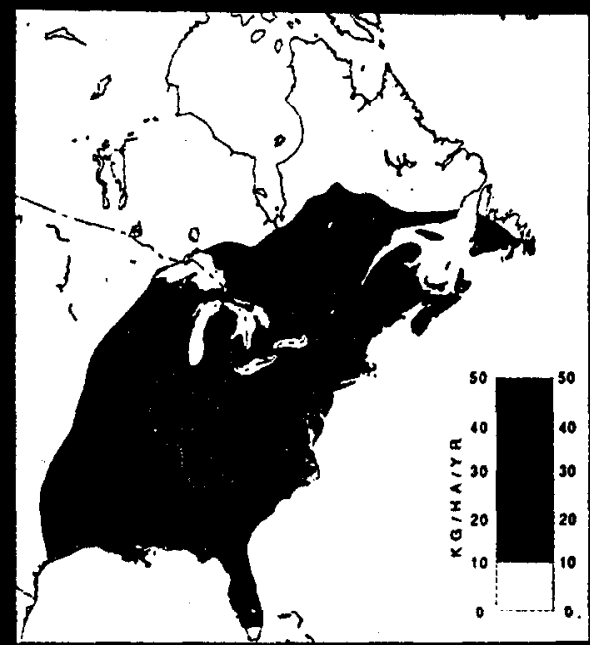

$1990-1993$

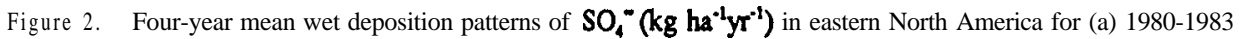
and(b) 1990-1993. Reproduced from EC (1997).

Areas in Canada within the $15 \mathrm{~kg}$ wet NO, ha ${ }^{-1} \mathrm{yr}^{-1}$ isopleth increased $13 \%$ from 373,000 ha in 1980-83 to 420,000 ha in 1990-93. Areas receiving at least $0.4 \mathrm{~kg} \mathrm{H}+\mathrm{ha}^{-1} \mathrm{yr}^{-1}$ decreased along the east coast and in southern Ontario, while the area receiving at least 0.2 $\mathrm{kg} \mathrm{ha}^{-1} \mathrm{yr}^{-1}$ expanded to the northeast (Newfoundland) and east (Nova Scotia) (Figures 4a,b) (EC, 1997). NO, and $\mathrm{NH}_{4}$ concentrations showed high variability, and deposition of $\mathrm{NH}$,, generally increased throughout the US (NAPAP, 1998). Acidification potential remains high over large forest areas due to increasing $\mathrm{NO}_{3}$ and decreasing $\mathrm{Ca}, \mathrm{Mg}, \mathrm{K}, \mathrm{Na}$ deposition (Likens et al., 1996).

Episodes have a large impact upon temporal changes in annual deposition amounts (Brook, 1995) and may increase annual mean SO, and $\mathrm{H}+$ deposition by $\leq 20 \%$ (Beattie and Whelpdale, 1989). In this context, precipitation amount and type are critical in pollutant deposition to forests, particularly those growing at mid to high elevation. Most mountain forests receive more $(>50 \%)$ precipitation than those at lower elevation; coastal forests are immersed in fog for up to $30 \%$ of the growing season. Mountain cloud/fog and coastal fog have been found to have extremely low mean annual weighted pH's, consistently 10-50X more acidic than precipitation (Kimball et al., 1988), with single events recorded as low as 


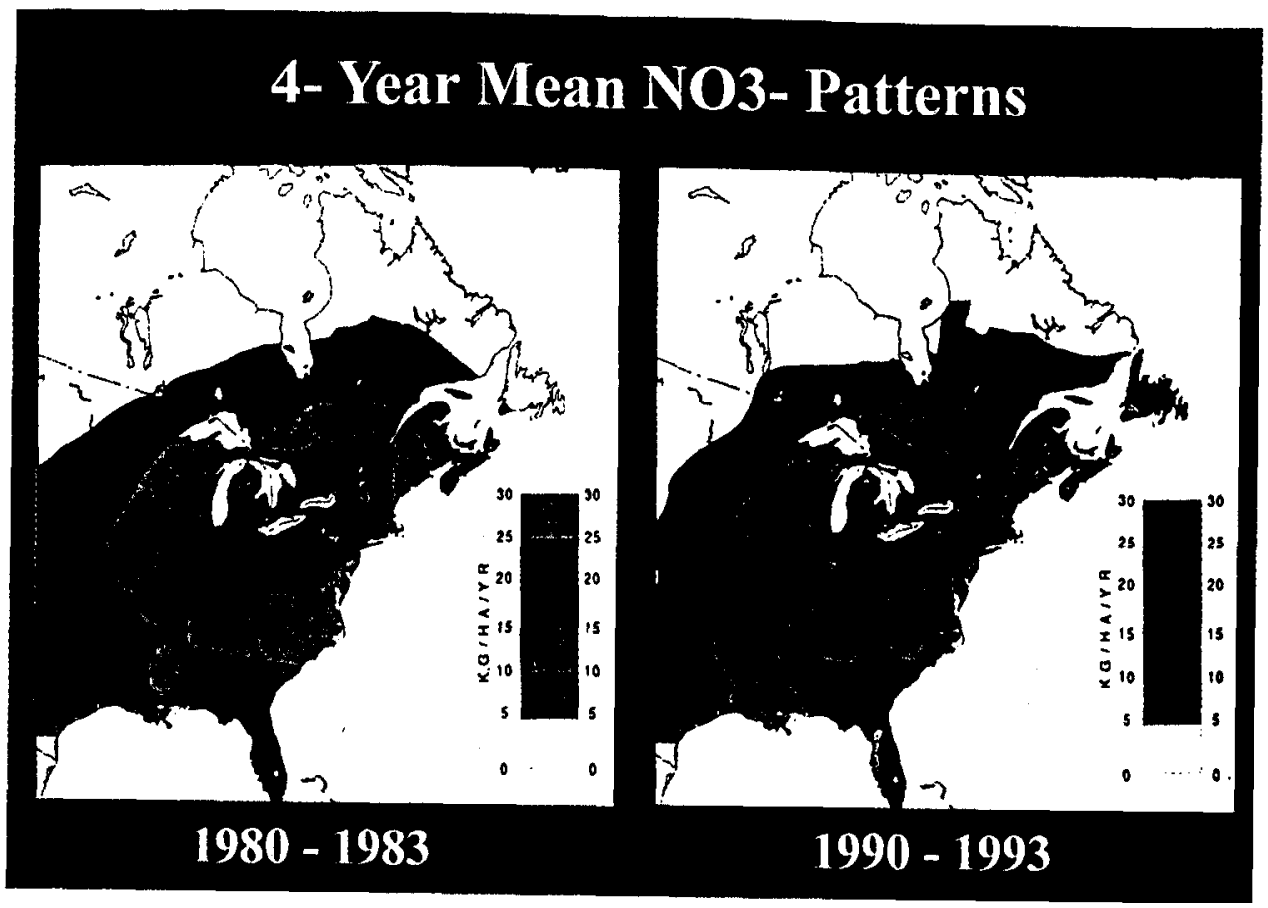

Figure 3. Four-year mean wet deposition patterns of $\mathrm{NO}_{3}^{-\mathbf{(}}\left(\mathrm{kg} \mathrm{ha}^{-1} \mathbf{y r}^{-1}\right)$ in eastern North America for (a) 1980-1983 and (b) 1990-1993. Reproduced from EC (1997).

pH 2.8. In the Southern Appalachian Mountains, cloud exposure at high elevation sites has been found to occur on $70 \%$ of the days and 30\% of the time (Saxena and Lin, 1990). In addition $25 \%$ of all cloud events over a 4 -year period had a $\mathrm{pH} \leq 3.1$ with a minimum $\mathrm{pH}$ of 2.2 (DeFelice, 1997).

Recent air quality modeling indicates that eastern regional deposition of SO., and NO, is much larger than amounts measured in precipitation (CAPMON, NADP) would indicate (EC, 1997). This raises the real possibility that inputs of acidic deposition to some forests may be substantially higher than estimated.

\subsection{OZONE}

Composite national daily maximum 1 hour 0, concentrations in the US decreased 15\% between 1987 and 1996. The highest national composite 1 hour maximum was in 1988. Ozone levels have declined 10\% since 1987 at 191 rural monitoring sites (EPA, 1998). In Canada, time series analysis identified a significant declining trend in daily maximum $\mathbf{O}_{3}$ concentrations ranging from $-0.05 \%$ to $-0.08 \% \mathrm{yr}^{-1}$. Average days per year (1986-1993) exceeding the $82 \mathrm{ppb} 1$ hour National Ambient Air Quality Objective (NAAQO) ranged 


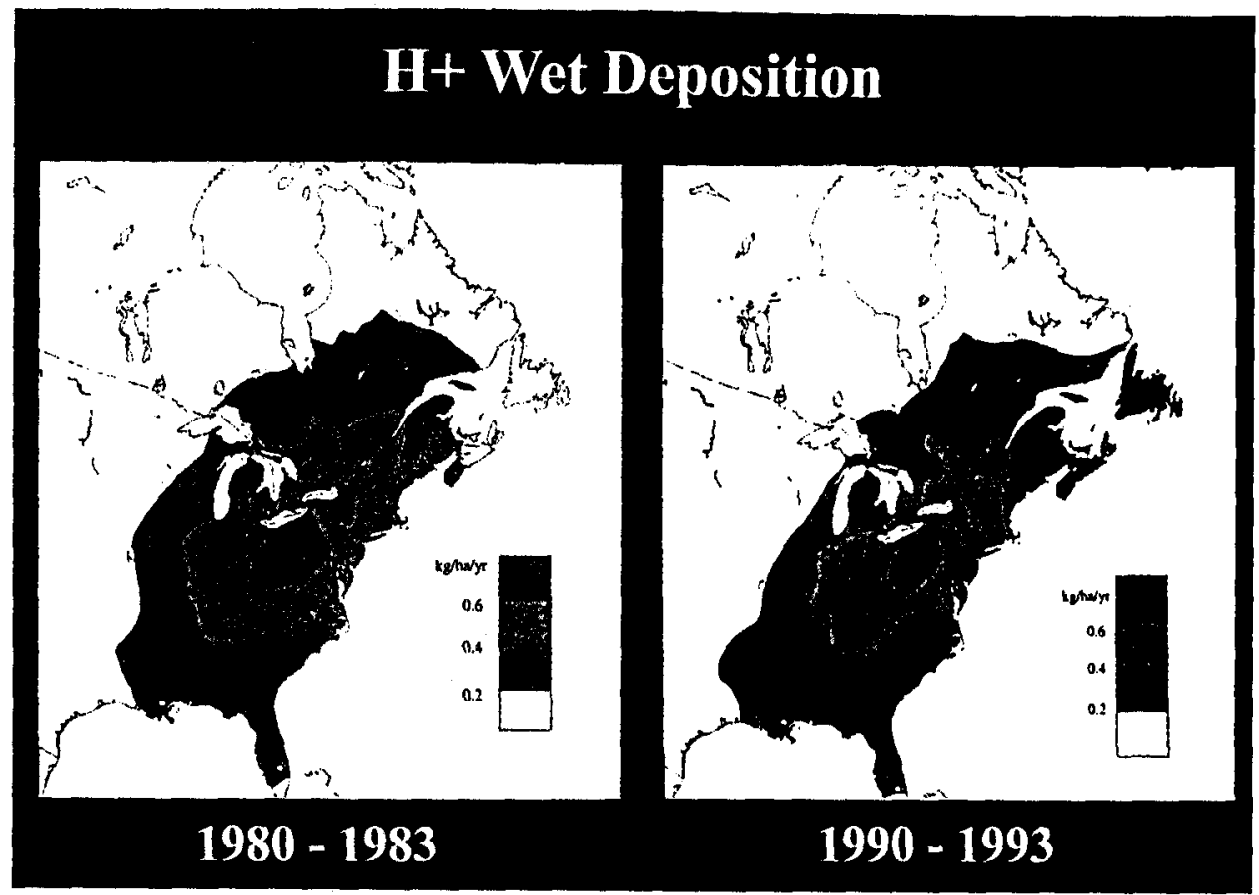

Figure 4. Four-year mean wet deposition patterns of $\mathrm{H}^{+}\left(\mathrm{kg} \mathrm{ha}^{-1} \mathbf{~} \mathbf{r}^{-1}\right)$ in eastern North America for (a) 1980-1983 and (b) 1990-1993. Reproduced from EC (1997).

from 18 in southern Ontario, 3 in the Southern Atlantic Region (SAR) and 2 in the Lower Fraser Valley, British Columbia.(Olivotto, 1997). Mapping of percent change in SUM60 between 1985-1987 and 1994-1996 shows a significant decrease of 10-15\% in much of the southeast US with decreases of $\mathbf{5 - 1 0 \%}$ or $\mathbf{0 . 5 \%}$ in the Lake States and southern Ontario/Quebec. Portions of the New England states and the SAR, however, had increases in SUM60 $\mathrm{O}_{3}$ of between $0-10 \%$. Smaller areas in the midwestem US showed increases of $10-15 \%$ SUM60 $\mathrm{O}_{3}$ (Figure 5).

Ozone (photochemical smog) and dry-deposited $\mathrm{N}$ remain the most abundant air pollutants in U.S. Pacific Southwest forests (Fujioka et al., 1998). In 1995, 99.3\% of $\mathbf{O}_{\mathbf{3}}$ exceedances occurred during June to October. The number of adverse episodes in the Los Angeles-Long Beach and Riverside-San Bernardino end of the Southern California Air Basin (SoCAB) declined during 1986-1995. However, the differential between the western (urban) and eastern (urban/forested) ends increased (EPA, 1997). The most abundant reactive compound in the San Bernardino Mountains is still $\mathrm{O}_{3}$, and ambient concentrations there are the highest in North America. Between November 2, 1991 and September 30, 1993, hourly concentrations exceeded the then-existing 120 ppb NAAQS on 235 days (22\% of sampling days). 

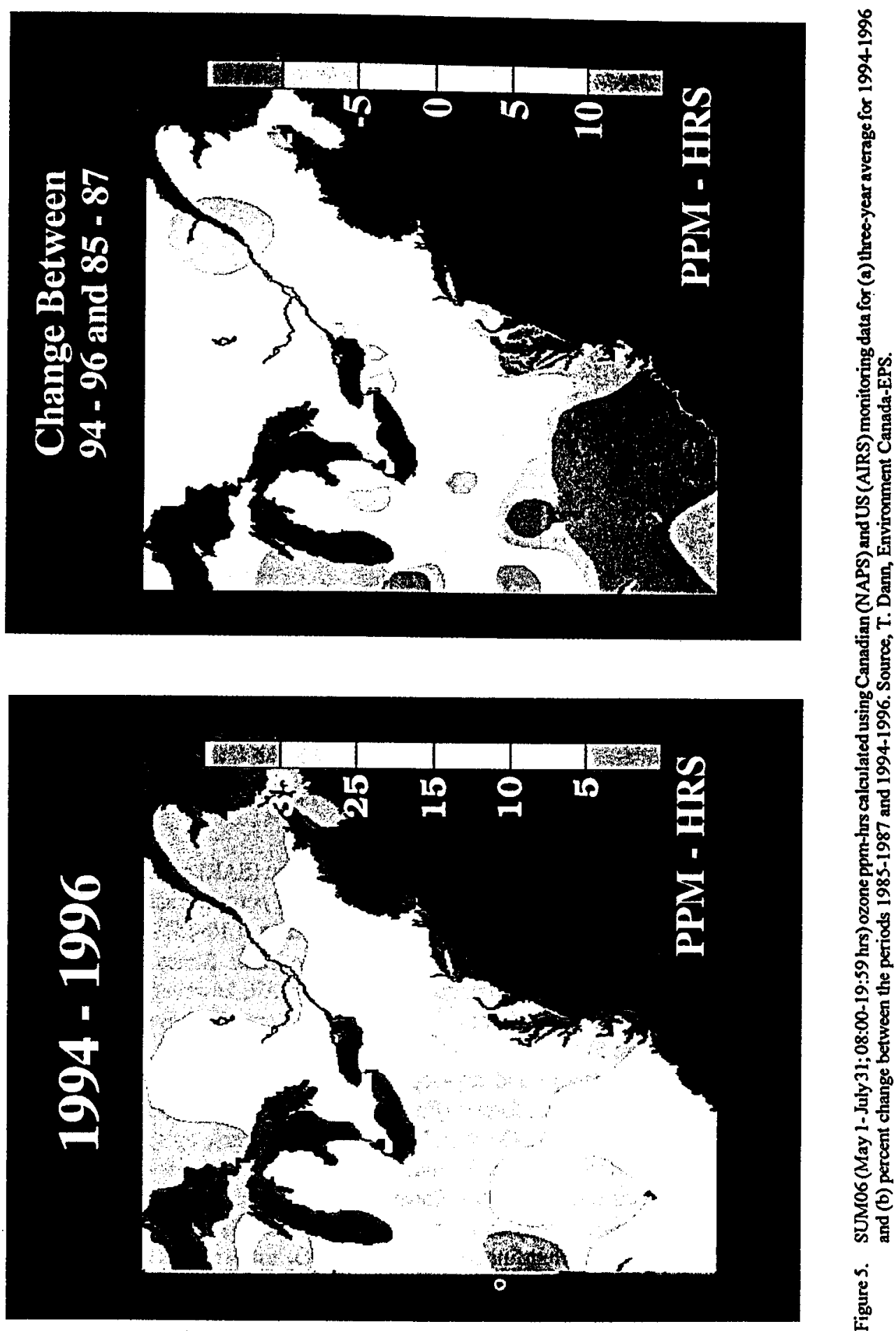


\section{Monitoring North American Forest Health}

In the 1980's, the rationale and protocols for the North American monitoring programs changed due to studies that indicated that widespread changes in forest condition were occurring in North America and Europe (Rehfuess, 1981, Ulrich, 1984, Schutt and Cowling, 1985; McLaughlin, 1985; Fraser et al. 1985, Prinz,1987). In Table I we have highlighted central features of both US, Canadian and European forest monitoring networks, and some details of their structure and focus are discussed below.

\subsection{THE UNITED STATES}

The Detection Monitoring component of the US Forest Health Monitoring Program (FHM) (USDA, 1992) was implemented in 1996 on about 40\% of approximately 4000 forested plots in the lower 48 states. A spatially and temporally systematic sample has been based on a national hexagonal grid (27 $\mathrm{km}$ between grid centres). The plot size and sampling frequency format (Table I) results in all circular 1 ha plots being sampled every 4 years with annual estimates of change being derived from smaller subplots (Smith and Mangold, 1996). This design yields: 1. a base-line condition the first year; 2 . a direct measure of 1year change for sub-plot samples after two years; and, 3. a direct measure of 4-year change after five years. Indicators (Table I) being measured in Detection Monitoring include lichen communities, ozone bioindicator plants, tree growth, crown condition, damage, mortality, regeneration, vegetation structure and plant diversity (Smith and Mangold, 1996).

\subsection{CanadA}

The Acid Rain National Early Warning System (ARNEWS) was initiated in 1984 @ 'Eon and Power, 1989). ARNEWS consists of 150 rectangular, $10 \mathrm{~m} \mathrm{X} \mathrm{40m} \mathrm{plots} \mathrm{with} 2 \mathrm{~m}$ x $2 \mathrm{~m}$ subplots stratified by forest region. The system currently contains about 11,700 trees (dbh $\geq 10 \mathrm{~cm}$ ) comprised of 3,500 hardwoods and 8,200 softwoods (Hall, 1995). Soil samples, foliar samples for nutrient analysis, and radial growth measurements are collected every five years adjacent to the plot (soil) or from numbered off-plot trees (foliage, increment cores). Variables are sampled on all plots at varying frequencies (Table I). Foliar symptoms, hardwood seed crop, pest conditions (type of foliar insect/disease, woody tissue insect/disease and severity) and tree condition (mortality, live crown height, crown damage, needle retention) are assessed seasonally and/or annually. Regeneration, saplings and

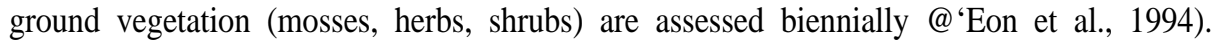

\subsection{JOINT UNITED STATES AND CANADIAN MONITORING}

Out of growing concern over sugar maple decline in the early 1980's, the USDA Forest Service and the Canadian Forest Service joined in 1988 with state and provincial agencies to establish the North American Maple Project (NAMP). NAMP consists of a network of 233 sites extending across the natural range of sugar maple (Acer saccharum Marsh) (Millers et al., 1991). NAMP sites are five-plot clusters of $20 \mathrm{~m}$ x $20 \mathrm{~m}$ plots on which all trees of $10 \mathrm{~cm} \mathrm{dbh}$ or more are identified. Stands ranged from 50 to 150 years of age in 1988 and had variable levels of damage or crown dieback. Sites were paired where possible, one being tapped and the other untapped (no tapping or management during previous 5 


\section{TABLE I}

Comparison of the United States Forest Health Monitoring (FHM), the Canadian Acid Rain National Early Warning System (ARNEWS), the North American Maple Project (NAMP) and the European (UN-ECE ICP) forest health monitoring programs.

$$
\text { Monitoring Program }
$$

FHM

No. plots

Plot strat.'

Plot visits

all

subset

Associated studies

Tree

diameter

height

dominance

form

crown height

crown closure

mortality

Crown

condition

symptoms

insects/diseases

foliage

defoliation

woody

seed production

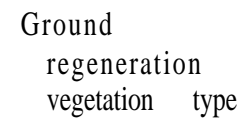

Pests

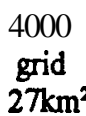

$27 \mathrm{~km}^{2}$

year $1 / 5$

$1 / 3$ year2

$1 / 3$ year 4

$1 / 3$ year 5

intensive site

E

E

E

X

$X$

X

$1-4$

1-4

14

$1-4$

$1-4$

$1-4$

14

$\mathrm{X}$

14

14

1-4
ARNEWS

150

forest

region

FIGC

none

166

na

1

NAMP

$U N-E C E$

20,345

grid $16 \mathrm{~km}^{2}$. 
TABLE I

Continued

Monitoring Program

FHM

ARNEWS

NAMP

UN-ECE

Nutrition

foliar $\mathrm{X}$

organic soil $\quad X$

mineral soil $\mathrm{X}$

5
5
5

$X$

$X$

X $\quad X$

Metereology/Air Quality

temperature

precipitation

$\mathrm{SO}_{4} / \mathrm{NO}_{3}$

4

X
X
X
B

$X$
$X$
$M$
$P$

$X$
$X$
$X$
$X$

$\mathrm{X}$

$X$

$\mathrm{X}$

B

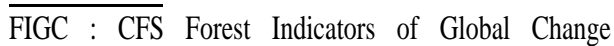

Sampling frequency: $5=5 \mathrm{yrs} ; 4=4 \mathrm{yrs} ; 2=2 \mathrm{yrs} ; 1=$ yearly; $S=$ seasonally (several times per year); $E=$ on establishment; $\mathbf{X}=$ not done

M: modelled; B: bioindicator plants; P: passive monitoring

1. Stratification of plots in network.

years). Variables assessed annually include defoliation, tree vigor, new damage to boles and crown condition (dieback, transparency).

The three forest health monitoring systems were designed to different protocols in order to address unique agency mandates. Each has specific strengths and weaknesses in responding to the monitoring of forest health response to changing air quality. In our view, none, by themselves, will enable forest managers or policy makers to relate effects to causes with the required degree of scientific certainty.

\subsection{INSECT AND DISEASE PROBLEMS IN NORTH AMERICA}

An important backdrop for consideration of pollution-induced stresses of North American forests is the extent of problems from insects and disease. A summary of the types of diseases, their approximate extent (where available) and the principal regions in which they have been detected, is given for the USA and Canada in Table II. Disease problems to forests are a major consideration in both Canada, where annual forest depletion due to disease during 1982-87 totaled 51 M cubic meters (NRCAN, 1996) and in the U.S.A., where the areal extent of insect problems on forests is $20.4 \mathrm{M}$ hectares (USDA, 1997). With this background we consider the types of physiological effects induced by regional air pollution from two perspectives: (1) the relative magnitude and distribution of effects attributable to air pollution; and (2) the potential for stresses from air pollution to interact with biotic and abiotic stresses. 
TABLE II

Estimates of forested areas affected by pests and pathogens in the U.S. and Canada in 1996.

Data are in millions $(\mathbf{M})$ of hectares (where available) by region,

\section{Ouantified}

united stated

Dwarf mistletoe (11.7 M-W), fusiform rust (5.5 M-SE)

Southern pine beetle (3.0 M-SE), spruce budworm (0.3 M-E + W)

Mountain pine beetle $(0.1 \mathrm{M}-\mathrm{NW})$, gypsy moth $(0.1 \mathrm{M}-\mathrm{NE})$

$\underline{\text { Unauantitied }}$

Beech bark disease (NE), butternut canker (NE)

Hemlock woody adelgid (NE), dogwood (E)

Anthracenose (NE, SE), European pine shoot beetle (NE, NC)

Total area affected $>20.4 \mathrm{M}$ ha

Guantitied $\underline{\text { Canada* }}$

Aspen 2-leaf tier (3.9 M-W), eastern spruce budworm (1.2 M-E)

Forest tent catepillar (1.2 M-Canada), other insects combined (7.1 M-Canada, W)

Other insects including area of beetle killed trees (4.6 M-Canada)

'Source: USDA (1997)

*Source: NRCAN (I 997)

\section{Regional Air Pollution: North American Case Studies}

Evidence of regional threats to forest health from air pollution in the U.S.A led in the mid1980s to the National Forest Response Program (Hertel and McKinney-McNeal, 1991), an integrated research program aimed at evaluating evidence and mechanisms of forest responses to acidic deposition and $\mathrm{O}_{3}$. Initial integrated summaries were produced around 1990 in the both the US (NAPAP, 1990) and Canada (Hall and Addison, 1991). The 1990 NAPAP synthesis included both studies of forest health (Barnard et al., 1990) and evaluation of process level changes associated with regional air pollution (Shriner et al., 1990). While very different in context (utilitarian vs ecosystem focus), the conclusions were similar in message - no clear cut evidence of a widespread forest decline, except for high elevation red spruce. Both analyses noted, respectively, uncertainty and evidence for pollution-induced changes in nutrient cycles and biotic and abiotic stress interactions that support longer term forest health. Canadian analyses in the NAPAP era, (Pearson and Percy, 1990) indicated that sugar maple decline was more severe and extensive than historically noted, and that acid deposition was a co-factor in a complex of contributing stressors. White birch decline along the east coast was circumstantially linked to acid fog. Critical loads were unavailable, but $46 \%$ of the Canadian land surface mapped was considered highly sensitive to acidification.

These first assessments have now been augmented by more recent syntheses of integrated studies (Eagar and Adams, 1992; Johnson and Lindberg, 1992; Fox and Mickler, 1995; Mickler and Fox, 1997) that were still in progress in 1990. Coupled with more recent results from Canadian studies (Hall, 1995; Hall et al., 1997) and synthesis of the long- 
standing ecosystem research on oxidant stress effects in the California ponderosa pine forests (Miller and McBride, 1998), additional valuable insights into the nature and extent of regional air pollution stress have been provided that we draw on here.

\subsection{SOUTHEASTERN PINE FORESTS}

The health of southern pine forests has been a subject of great interest and substantial controversy since significant growth declines were detected in the mid 1980's (Sheffield et al., 1985 and Sheffield and Cost, 1987). The evidence of unexplained growth reductions came from analysis of FIA inventory data from unmanaged pine stands by the US Forest Service. With an area of approximately $25 \mathrm{M}$ ha and annual stemwood sales of $\$ 4.5$ billion, the health of southern pines has been a major economic concern within the region. This concern translated into a large multiagency research effort aimed at quantifying causes of the apparent growth losses of the three predominant pine species in the region. The Southern Commercial Forest Research Cooperative (SCRFC), which was organized to address this task, conducted a series of regionally distributed controlled exposure studies with seedlings and saplings of loblolly pine (Pinus taeda L.), shortleafpine (P.echinata Mill) and slash pine ( $P$. elliota) to evaluate the potential of $\boldsymbol{O}_{3}$ and acidic deposition to affect southern pine growth. The summary of forest characteristics, biotic and abiotic stresses, and potential impacts of acidic deposition and ozone for southern pine forests combined information gathered in epidemiological and mechanistic studies over approximately 8 years of research (Pox and Micker, 1995).

A summary of the results of controlled exposure studies with seedlings and saplings of southern pines in open-topped chambers in the SCFRC indicated that significant growth reductions occurred with increased ozone esposure, but no consistent adverse effects of acidic deposition were detected (Teskey, 1995). Most studies reported small reductions in growth at ambient ozone, estimated at $\mathbf{2 - 5} \%$ per year, but these reductions were not typically detectable statistically within the experimental constraints of the experimental systems employed (Teskey, 1995). Contributing to this variability were genetics (multiple families with very different sensitivity levels), treatments imposed (interactions of ozone and acid deposition) and substantial year to year variability in ambient-based treatments imposed.

Additional analyses of the combined results of a wide range of controlled ozone studies with loblolly pine emphasized the role of high genetic variability in sensitivity in growth responses to ozone, particularly at near-ambient levels (Taylor, 1994). Using this much larger data set, Taylor (1994) estimated an ozone response threshold of $33 \mathrm{ppm}$ hrs and a 6\% growth loss per $100 \mathrm{ppm}$ hrs of ozone exposure for sensitive families. The threshold for the population mean was similarly estimated at $97 \mathrm{ppm}$ hrs with a $3 \%$ growth loss per $100 \mathrm{ppm}$ hrs of cumulative exposure. At typical annual ambient ozone exposure levels of 50-200 ppm hrs (Taylor, 1994), estimated annual growth losses during a single season were $1-10 \%$ for sensitive families and $0-3 \%$ for the mean population.

Several studies have now indicated that the effects of ozone exposure are cumulative and approximately linear. The concept, which apparently extends to effects occurring over multiple seasons, is supported by studies of both loss ofphotosynthetic capacity (Richardson et al., 1992) and foliage production and retention (Stow et. al., 1992, Kress et al., 1992). Reduced canopy photosynthesis was noted at a cumulative exposure threshold of 100-150 ppm hrs and reduced foliar retention occurred at 150-230 ppm hrs. An important principal 
established in these analyses was the carryover of inhibition of photosynthetic potential of ozone impaired foliage into subsequent growing seasons (Sasek et al., 199 1).

Studies of responses of more mature loblolly pine trees have included modeling-based estimates developed around changes in gross primary production of branches (Dougherty et al., 1992); regional application of a physiologically-based model with regional ozone exposure data (Hogsett et 1.1993); and empirically derived measures of tree growth responses in the field (Zahner et al., 1989, and McLaughlin and Downing, 1996). Results of these analyses for pines and selected studies with hardwoods are summarized in Table III and indicate an expected response range of $\mathbf{0 - 3 5 \%}$ annual growth reduction for mature pines, depending on species $\mathbf{X}$ year and ozone level. Work by McLaughlin and Downing (1997) and Zahner et al. (1989) support the possibility that sensitivity of mature trees to drought may be enhanced by ozone at levels occurring in the field. Using an empirically derived model from weekly growth responses of mature loblolly pine trees to ozone in the field, McLaughlin and Downing (1996) indicated that ozone significantly increased the effects of soil moisture stress on stem growth. This concept is supported by studies with pine seedlings and saplings at ambient or near-ambient ozone levels which document increased transpiration (Lee et al., 1990) or increased water stress (Flagler et al., 1997). In addition several European studies with saplings and mature conifers (Skarby et al., 1987; Wallin and Skarby, 1992; Maier-Maercker and Koch, 1992; Maier-Maercker, 1997), have reported increased transpiration and/or reduced stomatal control of water loss for conifers at ambient ozone levels. Collectively these studies suggest that stomatal closure measured at high ozone levels with seedlings in some controlled exposure studies, may not adequately represent the expected response to ambient exposures in the field, particularly where large trees are involved.

SCFRC studies indicated a low short-term risk to growth from ambient exposure to acidic deposition, and in fact growth was typically stimulated by near-ambient levels (Teskey, 1995). However, acidic deposition exerts it's effects primarily through nutrient mobilization and depletion, and the development of such effects in controlled studies will depend on initial soil nutrient content and soil volume, factors which affect the capacity for nutrient depletion. Of greater relevance from the perspective of evaluating risk to southern pines, is the regional distribution of pine stands on poorly-buffered soils depleted of base cations by previous agricultural practices. Approximately $60 \%$ of southeastern pine soils are considered to be susceptible to accelerated cation leaching (Richter and Markewitz, 1995). Binkley et al., (1989) have estimated that 10-15\% of commercial southern pine forests may be currently limited by low base cation supply. Long term studies of nutrient cycles at a reference watershed in South Carolina indicate that approximately $80 \%$ of the exchangeable calcium $(\mathrm{Ca})$ has been lost from the soil over the past three decades, with $50 \%$ of this loss due to uptake by vegetation and 50\% due to leaching (Richter et al., 1994). Base saturation declined from $\geq 55 \%$ in 1962 to $20 \%$ in 1972, and to $10 \%$ in 1990 . This decline was most apparent in shallow soil profiles $(<20 \mathrm{~cm})$ where fine roots are concentrated (Richter and Markewitz, 1995). In considering the potential negative effects of Ca depletion from these soils, it should be noted that many of these same soils are $\mathrm{N}$ deficient and are receiving $4.5-14 \mathrm{~kg} \mathrm{~N} / \mathrm{ha} / \mathrm{y}$, approximately $15-45 \%$ of annual stand requirements, from atmospheric sources (Richter and Markewitz, 1995). Accumulation of $\mathrm{N}$ in the upper soil horizons has the potential to stimulate growth at the risk of longer term cation depletion, as we will discuss later. 
T A B L E II I

Some estimates of effects of ozone on prowth of forest tree snecies at ambient ozone levels based on studies with seedlings and mature trees.

\section{SEEDLING STUDIES}

\begin{tabular}{|c|c|c|c|}
\hline Growth & h Reduction & $\underline{\text { Conditions }}$ & \\
\hline Multiple & $0-10 \%$ & shootgrowth & $\begin{array}{l}\text { Chappelka and } \\
\text { Samuelson, } 1998\end{array}$ \\
\hline southern pines & $2-5 \%$ & $\begin{array}{l}\text { summary estimate - SCFRC } \\
\text { field-chamber studies }\end{array}$ & Teskey, 1995 \\
\hline \multirow[t]{2}{*}{ Loblolly pine } & & Synthesis $\bullet$ whole tree biomass & Taylor, 1994 \\
\hline & $\begin{array}{l}\mathbf{0 . 3} \% \\
1.10 \%\end{array}$ & $\begin{array}{l}\text { Mean response and sensitive } \\
\text { family response to } 50-200 \mathrm{ppm}^{\star \mathrm{h}}\end{array}$ & \\
\hline $\begin{array}{l}\text { Hardwoods } \\
\text { Conifers }\end{array}$ & $\begin{array}{l}13 \% \\
3 \%\end{array}$ & $\begin{array}{l}\text { Response surface derived values } \\
\text { at } 20 \mathbf{p p m}^{*} \mathbf{h}\end{array}$ & Reich, 1988 \\
\hline & & MATURE TREE STUDIES & \\
\hline Loblolly pine & $2.9 \%$ & $\begin{array}{l}\text { Whole tree carbon model using } \\
\text { branch chamber data }(\mathrm{GA})\end{array}$ & Dougherty et al., 1992 \\
\hline \multirow[t]{3}{*}{ Loblolly pine } & $0-13 \%$ & $\begin{array}{l}\text { Average annual weekly responses } \\
\text { to } \mathbf{O}_{\mathbf{3}} \text { and interactions of } 0 \text {, and } \\
\text { moisture stress, } 5 \text { years }(\mathrm{TN})\end{array}$ & $\begin{array}{l}\text { McLaughlin and } \\
\text { Downing } 1996\end{array}$ \\
\hline & $0.5 \%$ & Annual 0 , effect no water stress & $\begin{array}{l}\text { McLaughlin and } \\
\text { Downing } 1996\end{array}$ \\
\hline & $0-30 \%$ & Annual $\mathbf{O}_{\mathbf{3}}$ effect moderate water stress & $\begin{array}{l}\text { McLaughlin and } \\
\text { Downing } 1996\end{array}$ \\
\hline Loblolly pine & $5-12 \%$ & $\begin{array}{l}\text { Regional forest model simulation } \\
\text { based on small tree exposures }\end{array}$ & Hogsett et al., 1993 \\
\hline Shortleaf Pine & $1 \% \mathrm{y}^{-1}$ & $\begin{array}{l}\text { Empirically derived growth loss } \\
38 \% \text { cumulative not explained by } \\
\text { climate and competition. Natural stands } \\
20-45 \text { yr (GA, SC, NC) }\end{array}$ & Zahner et al., 1989 \\
\hline Shortleaf Pine & Climatic shift & $\begin{array}{l}\text { Dendroclimatic analysis , Increase } \\
\text { in non-climatic influences } \\
\text { beginning in } 1963 \text {. (GA)' }\end{array}$ & $\begin{array}{l}\text { Grissino-Mayet and } \\
\text { Butler. } 1993\end{array}$ \\
\hline White Pie & $0,>$ climate & $\begin{array}{l}\text { Dendroclimatic analysis show } 0, \\
\text { influences growth more than } \\
\text { climate (ME) }\end{array}$ & $\begin{array}{l}\text { Bartholomay et } a l ., \\
1997\end{array}$ \\
\hline Hardwoods & $2 \cdot 17 \%$ & $\begin{array}{l}\text { Regional simulation with } \\
\text { canopy-stand model across } \\
\text { moisture gradients }\end{array}$ & Ollinger et al., 1997 \\
\hline
\end{tabular}




\subsection{SOUTHWESTERN PINE FORESTS}

In the San Bernardino Forest, ponderosa pine (Pinus ponderosa Dougl. Ex Laws), one the most important forest species in California (Olson, 1992), is exposed to the highest ozone concentration in North America by topographical, meteorological and climatic influences which combine to advect the Los Angeles urban pollution plume inland along the western mountain slopes (Miller, 1992). The resultant chronic exposure and ecosystem level changes in the San Bernardino Forest Ecosystem to over 50 years of high levels of $\boldsymbol{O}_{\mathbf{3}}$ and oxidant air pollution has produced perhaps the best example of hierarchical forest response to air pollutants (Miller et al., 1982; Miller et al., 1989; Miller, 1992; Miller et al., 1996). Ozone injury to the mixed conifer forest has been occurring since at least the mid-1950's in the mountains of Southern California (Miller and Millecan, 1971) and since the 1970's in the Sierra Nevada (Pronos et al., 1978). Miller et al. (1963) were first to identify the classic $\mathrm{O}_{3}$ symptomology and chlorotic foliar mottle associated with the injury. Species most affected by photochemical oxidants (mainly $\mathrm{O}_{3}$ ) have been ponderosa and Jeffrey (Pinus jeffreyi Grev. and Balf.) pines.

Injury to pine foliage resulted in a decline in the health of sensitive trees; accumulation of weakened trees then resulted in a heavy bark beetle kill. This necessitated extensive sanitation logging to remove declining pine trees. Unable to compcte for nutrients, water and light, remaining sensitive individuals declined allowing for enhanced growth of more tolerant species (Miller et al., 1982). Chronic effects of $\mathrm{O}_{3}$ and $\mathrm{N}$ compounds continue today. The area has been used as a natural laboratory to study the air pollution effects on ecosystem functioning, including human values, and the 30 year San Bernardino Case Study is now summarized in Miller and McBride (1998).

During early survey years of 1968-1972 $\mathrm{O}_{3}$ concentrations were extremely high (>80 ppb $\mathrm{O}_{3}$ for $1300 \mathrm{~h}$ for a five-month year). Ponderosa and Jeffrey pine mortality ranged from $8-10 \%$ (2-2.5\% per year). Ozone concentrations at high elevation sites remained above 50 $\mathrm{ppb}$ at night. An increase in extent of severe foliar injury indicated the beginning of the selective death of ponderosa pine (Miller, 1973). Weakened trees were attacked by bark beetles and elimination of ponderosa pine from the mixed conifer forest was predicted (Cobb and Stark, 1970). This survey led to the establishment of a large, multidisciplinary research team to investigate essential ecological processes underlying mixed conifer forest response to $\mathrm{O}_{3}$. A hierarchical response, parallel to that observed with eastern white pine (Pinus strobus L.) (McLaughlin et al. 1982), was documented. Average $(24 \mathrm{~h})$ concentrations of 50-60 ppb 0,: induced foliar injury leading to premature abscission; needle fall resulted in reduced photosynthetic capacity; decreased nutrient availability to stressed trees; reduced production of carbohydrates; and diminishing tree vigor resulting in decreased height and radial growth (Miller et al., 1982). At the ecosystem level, changes in decomposition patterns and altered nutrient cycling altered successional patterns in some species. This cycle of interactions triggered by $\mathrm{O}_{3}$ on sensitive individuals significantly altered ecosystem processes and intra-community relationships. Unlike a catastrophic event such as fire, tree death and associated energy changes within the ecosystem occur gradually. Understanding of such changes in tree vigor, species composition, energy flow, nutrient cycling, and interactions between trophic levels is critical if cause-effect relationships are to be adequately evaluated..

One test of cause-effect linkage is mixed conifer forest response to gradually diminishing $\mathrm{O}_{3}$ stress. Miller et al. (1989) reported an improvement (1974-1988) in foliar 
injury index at all but the most exposed plots in the San Bernardino Mountains in response to declining $\mathrm{O}_{3}$ in 1976-1991(Davidson, 1993). Changes in visual injury were paralleled by improving tree growth patterns. Growth plots in a high-O, exposure area along the southern rim of the San Bernardino Mountains showed an approximate $40 \%$ growth slowdown during the period of highest ozone (1945-72) with a recovery of basal area growth to pre-1945 levels during the most recent period of improved air quality (Arbaugh et al., 1998). The concurrence of long-term reduction in precipitation and high $\mathbf{O}_{\mathbf{3}}$ were concluded to be responsible for the growth pattern, and not $\mathbf{O}_{3}$ alone. However, a significant lag in integration of improved canopy condition into improved basal area (BA) growth was identified. $\mathrm{BA}$ increases in $\mathrm{O}_{3}$ - sensitive ponderosa pine during the same period (Miller et al. 1991) remained less than the $\mathrm{BA}$ increase for $\mathbf{O}_{\mathbf{3}}$ tolerant species. Only continued ecosystem monitoring will define the new baseline.

Evidence has existed for some time (Hoffer et al. 1981) that polluted air masses accumulating over central California are transported into the Sierra Nevada Mountains (Stohlgren and Parsons, 1987). Surveys recently completed in national parks in the region documented a progression of foliar symptoms on ponderosa pine related to aspect and elevation (Peterson et al. 1991). Standardization of an index to assess crown injury on ponderosa and Jeffrey pines, the Ozone Injury Index (OII), occurred in 1989. The Sierra Cooperative Ozone Impact Study (SCOIAS) and the Forest Ozone Response Study (FOREST) were among the first reports linking crown assessment, including both foliar injury and needle retention, with cumulative ambient $\mathrm{O}_{3}$ indices. This represents a potentially reliable, cost effective approach for monitoring and forecasting $\mathrm{O}_{3}$ injury in remote areas (Arbaugh et al. 1998).

Critical co-factors affecting tree response in SCOIAS/FOREST were site climate, history, tree size and age, $\mathrm{N}$ deposition and genetics. The unique role of $\mathrm{N}$ deposition in the mixed conifer forests of California has been well established (Bytnerowicz and Fenn, 19\%). Unlike other case studies, most deposition occurs in summer in dry $\mathrm{N}$ form as acidic vapor, gaseous and particulate species. Deposition may be as high as $25-45 \mathrm{~kg} \mathrm{~N} \mathrm{ha}^{-1} \mathrm{yr}^{-1}$ and has resulted in localized $\mathrm{N}$ saturation in some mixed conifer stands (Bytnerowicz and Fenn 1996).

In summary, the effects of chronic exposure of these forests to acidic deposition and $\mathbf{O}_{\mathbf{3}}$ were detected on forest health through intensive process research built upon a historical record of individual tree response (Miller et al. 1996; Bytnerowicz et al. 1998). The multidisciplinary study succeeded in providing a comparative database on mixed conifer forest exposed to moderate and high levels of gas and particle deposition. Acidic pollutants, despite extreme sensitivity of leaf surface wax to acidic hydrolysis by $\mathbf{H N O}_{3}$ (Bytnerowicz et al 1998), were not implicated in a short-term response. The interaction of $\mathrm{O}_{3}$ with periodic droughts (Miller et al. 1996), in the long-term, and summer N pulses (Bytnerowicz et al. 1998), in the very short-term, were judged to be the greatest threats to the health of southwestern pine forests

\subsection{EASTERN SPRUCE-FIR FORESTS}

High levels of mortality of red spruce (Picea rubens Sarg.) in the Northern Appalachians (Weeks and Smoronok, 1988) and Fraser fir (Abies fraseri (Pursh) Pair.) in the Southern Appalachians (Dull et al., 1988) during the 1970's and 1980s were accompanied by reductions in radial growth of red spruce at many high elevation sites across the region 
(Johnson and Siccama, 1983; McLaughlin' et al., 1987). The timing and distribution of observed changes in growth suggested a possible linkage to acidic deposition and an integrated series of field and laboratory studies was conducted over the interval 1987-1991 by the Northern Spruce Fir Research Cooperative (NSFRC, Eagar and Adams, 1992). A synthesis of this work concluded that both field and laboratory data support " --that regional scale air pollution has played a significant role in the decline of red spruce in the Eastern United States" (Johnson et al., 1992). This was based on regional and local analysis of the epidemiology and distribution of increased tree mortality and canopy deterioration (Peart et al., 1992); the timing and distribution of radial growth decline of mature trees (Cook and Zedaker, 1992); and mechanistic studies in the field and laboratory which linked changes in carbon allocation (McLaughlin and Kohut, 1992) and winter injury (DeHayes, 1992) to levels of acidic deposition monitored within the region (Mohnen, 1992). These studies represent an excellent model of effective integration of regional monitoring of forest condition with mechanistic studies designed tobetterunderstand observed responses. In this case, multiple lines of investigation yielded new mechanistic insights linking acidic deposition as a predisposing agent to increased stress of red spruce forests by abiotic stress. These included both winter injury and nutrient depletion from foliage and soils. A summary of the principal trends in responses observed in field studies from the Northern Appalachians is depicted in Figure 6.

Increased winter injury to current year foliage was an important symptom of damage detected on red spruce in the Northeastern mountains in the late 1950s and early 1960's (Friedland $\boldsymbol{e}$ t al., 1984). As this damage was repeated frequently over the following years, clear linkages were found to reduced radial growth of both montane and coastal red spruce forests (Jagels, 1986 and Percy et al., 1993) and increased mortality of montane trees (Johnson et al., 1992). By the mid 1980's increased mortality levels had reduced red spruce as a component of the high elevation canopy by $\geq 50 \%$ in the Adirondack and Green Mountains and by $25 \%$ further North in New Hampshire and Maine. A dendroclimatological analysis of the growth decline for trees from affected areas revealed that the occurrence of increased winter injury was a consequence of increased sensitivity of trees to winter temperatures, not unusually cold winters (Cook and Johnson, 1989). A series of misting experiments with acidic deposition under controlled laboratory conditions (see Dehayes, 1992) coupled with exclusion studies with branches (Vann et al., 1992) and chambered saplings (Dehayes et al., 1991) at high elevation field sites indicated that ambient levels of acidic mist could reduce the cold hardiness of red spruce by $3-10^{\circ} \mathrm{C}$. This is an amount sufficient to substantially increase winter injury to this species at high elevation northeastern sites (Johnson et al., 1992).

The growth decline of high elevation red spruce in the Southern Appalachians began typically around 1965, 5 years later than in the North, was confined to elevations above $1700 \mathrm{~m}$, and was not accompanied by the very high red spruce mortality levels of the Northern Appalachians (McLaughlin et al., 1987). However, canopy condition of red spruce declined significantly at both high and low elevation sites during 1985-89 (Peat-t et al., 1992) and average red spruce mortality was consistently higher (ranging from $3-4 \%$ per year) at high elevation sites than intermediate and lower elevations (Nicholas, 1992). Standing dead red spruce comprised $\mathbf{8 - 1 7 \%}$ of the stands at high elevation sites where attrition of dead stems was found to be remarkably high - 33\% per year (Nicholas, 1992). While a notable loss in basal area of red spruce has not yet been reported at the southern Appalachian sites (Smith and Nicholas, 1998) mortality has occurred across all size classes 
Northern Appalachilan Composite Chronology
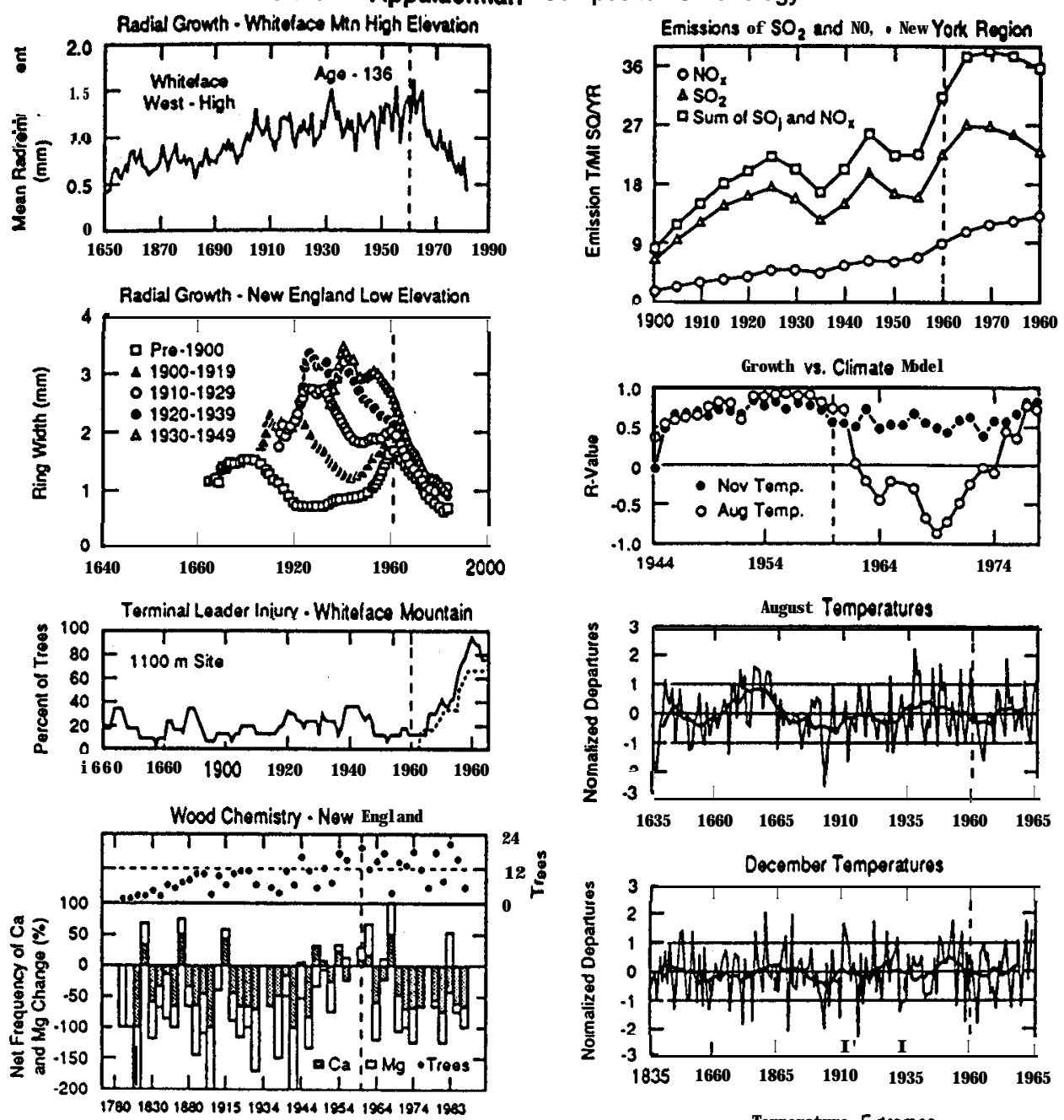

Winter Damage to Fol $\mathrm{i}$ age. Whitolace Mountain
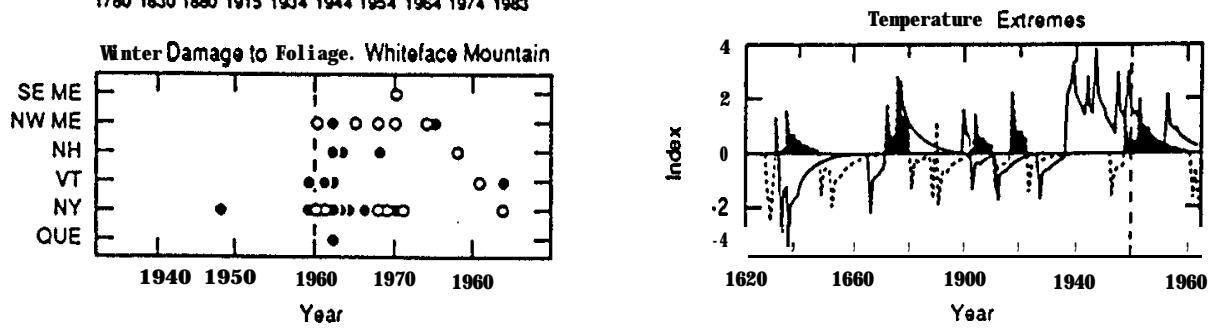

Figure 6. Results of many different analyses revealed a shift in the health of high elevation red spruce around 1960 corresponding to increasing loading from acidic deposition in the Northern Appalachian Mountains (After Johnson et al., 1992). In summary left panels (top to bottom) describe reduced radial growth at high and low elevations, increased terminal leader mortality, shii in wood cation chemistry, and increased frequency of winter injury to foliage. The timing of these changes coincidea with sharp regional increases in emissions of $\mathrm{S}$ and $\mathrm{N}$ (upper right) and shifts in growth climate relationships that were not attributable to unusual climate (lower right panels). See Johnson $\boldsymbol{e}$ al. (1992) for sources and details. 
and available data indicate that recruitment levels are only approximately $50 \%$ of mortality levels (Nicholas, 1992).

Physiological studies in the field at both Southern and Northern Appalachian sites have shown that reduced cation availability associated with atmospheric deposition of strong anions reduces net carbohydrate production by foliage (McLaughlin et al. 1990, 1991,Amundson et al., 1992; and Schaberg et al., 1997). Reduced growth, decreased photosynthesis, increased respiration, and foliar cation depletion observed in the field were reproduced with red spruce seedlings under controlled conditions with ambient range $\mathbf{p H}$ 3.0) acidic mist (McLaughlin et al., 1993). Reduced Ca availability induced by both interference with root uptake of $\mathrm{Ca}$ from the soil and increased leaching of $\mathrm{CA}$ from foliage by acidic mists appear to be an essential feature of observed responses in these studies (McLaughlin and Kohut, 1992). Changes in membrane-associated Ca have now been linked to changes in winter hardiness of red spruce (DeHayes et al., 1997) and subsequent controlled studies have shown that acid mist exposures can alter membrane-associated $\mathrm{Ca}$ and reduce winter hardiness of red spruce by $10^{\circ} \mathrm{C}$ (DeHayes et al., 1999).

Dendroecological studies in the South (McLaughlin et al., 1987 and McLaughlin et al., 1998) in parallel to those in the North (Cook and Johnson, 1989) indicate that reduced growth of mature trees is associated with sensitivity to warmer late summer temperatures. These responses suggest that carbohydrate depletion by increased dark respiration, a physiological symptom associated with Ca deficiency (Bangerth, 1979 and McLaughlin and Wimmer, 1999), may have contributed to observed growth losses. Winter damage to foliage has not occurred to any significant extent in the Southern Appalachians, although a less severe chlorotic stippling, which accumulates over winter with increasing needle age has been detected (Anderson et al., 1991). The absence of severe foliage loss may explain the lower mortality generally observed in southern red spruce stands. On the other hand foliar and soil Ca levels are generally lower (Joslin et al., 1994) and soil solution aluminum levels are substantially higher at southern sites where soil solution $\mathrm{Ca}: \mathrm{Al}$ levels $\leq 0.50$ occur frequently at some high elevation sites (Johnson et al., 1991).

While most of the research in the spruce fir ecosystem has been directed at red spruce, significant mortality has also occurred in co-dominant and closely-related balsam fir (Abies balsamea (L.) Mill) in the North (Weeks and Smoronok, 1988) and Fraser fir in the South (Dull et al., 1988). Observed declines of these species are regarded by most to be primarily a natural phenomenon linked to cohort senescence (fir waves) and insect damage from the balsam wooly adelgid (Adelges fraserii). However the influence of Ca deficiency on a wide variety of plant processes including both senescence and disease resistance (Pooviah, 1988) suggests that consideration of the role of $\mathrm{Ca}$ deficiency in predisposing trees to these stresses is warranted (McLaughlin and Wimmer, 1999). In the South, growth declines of mature fir began about 1965 (Adams et al., 1985) at the same time that adelgid damage was first detected at multiple mountain sites (Eagar, 1981). Physiological studies of Fraser fir indicate that increased dark respiration linked to reduced $\mathrm{Ca}$ and increased elevation, parallels symptoms noted for red spruce (McLaughlin et al., 1997). In the North, aggrading stands of balsam fir grew more slowly at high elevations compared to those of the same age at lower elevations after 1960 (Reiners and Lang, 1979), indicating that this species has experienced increasing stress at high elevation sites during the same time interval over which red spruce has been adversely affected by acidic deposition. 


\subsection{NORTHEASTERN HARDWOOD FORESTS}

Abnormally high levels of mortality have been recorded for several species of hardwood trees in the northeast since the 1980's. Most concern has centered on sugar maple forests across large areas in Ontario, Quebec, Vermont and New Hampshire.

Extensive crown dieback and mortality of sugar maple was first detected during the late 1970's and early 1980's. By 1982, decline symptoms were evident across 2,000 km² of sugar maple forest in Quebec alone (Roy et al., 1985). A sustained recovery of these maples has occurred since then with dieback and mortality now reduced to historical levels (Hall et al., 1997). Hall (1995) reportedsugarmaple had an annual mortality of $0.9 \%$ during $1987-1993$ with tree condition showing little yearly change. Similarly NAMP data collected during 1985-96 in the US showed the condition of sugar maple trees $(n>4,000)$ in the New England and New York region was good during 1988-1996. Mortality averaged between $0.9 \%$ and $1.9 \%$ per year (Stoyenhoff et al., 1998). Crown condition improved with transparency declining from over $18 \%$ in 1988 to less than $12 \%$ in 1996. Dieback declined from circa $7 \%$ in 1988 to circa $6 \%$ in 1996. No difference was determined for the health of sugar maple growing in sugarbush and non-sugarbush stands. In Canada condition of sugar maple crowns on NAMP (62 sites) plots generally improved from 1988 to 1993, particularly in Quebec which had the highest level of dieback in 1988 (Lachance et al., 1995). Dieback ranged from 5.3\% to $8.2 \%$ during 1988-1993 while transparency ranged from $9.1 \%$ to $21.6 \%$. As in the US, crown condition and mortality did not differ between sugarbush and non-sugarbush stands.

While no relationship was initially found between average NAMP cluster dieback/transparency and average five-year mean wet $\mathrm{SO}_{4}$ or $\mathrm{NO}_{3}$ deposition (Lachance et al., 1995), subsequent analyses based on regional differences in soil buffering provided additional insights. In initial analyses relationships were tested using deposition values from air monitoring stations not collocated with plot clusters and data were averaged regionally into three zones (low, medium, high). In subsequent analyses atmospheric deposition rates were superimposed on soil acidification potential based on criticals load calculation. Esceedances of critical loads were calculated (Arp et al., 1996) for ARNEWS plots (Figure 7), and these analyses indicated that the majority of the plots located north of the limestone region in extreme SW Ontario experienced high exceedances of the calculated critical loads (Hall et al., 1997). Arp et al. (1996) also reported using NAMP data for Ontario, that areas of critical load exceedance had consistently higher levels of branch dieback than areas of no exceedance. Hall et al. (1997) state that within the Canadian Shield, attainment of a 50\% reduction in the greatest critical load exceedance would require a reduction of SO, deposition rates to $12 \mathrm{~kg} \mathrm{ha}^{-1} \mathrm{yr}^{-1}$ (See Figure 2).

Linkage of tree response to soil sensitivity to acidic deposition is closely tied to soil supply capacity for base cations. This is apparent in the northern Appalachians, where nutrient deficiencies $\mathrm{K}$ and $\mathrm{Mg}$ were initially associated causally with sugar maple decline (Bernier and Brazeau, 1988a,b; Bernier et al. 1989). This was supported by responses to fertilization with $\mathrm{K}$, which improved foliar nutrient status and growth rates in declining maples (Ouimet and Fortin, 1992), and fertilization with $\mathrm{Ca}$ and $\mathrm{Mg}$, which led to improved tree vigor (Hendershot, 1991). Studies in mature stands have confirmed that ambient levels of acid deposition have accelerated the loss of base cations from soils (Foster et al., 1992) leading to reduced soil $\mathrm{Ca}, \mathrm{Mg}$ and $\mathrm{K}$ concentrations in sugar maple stands. These effects have been greatest where deposition is highest (Morrison et al., 1996). Similarly, liming 


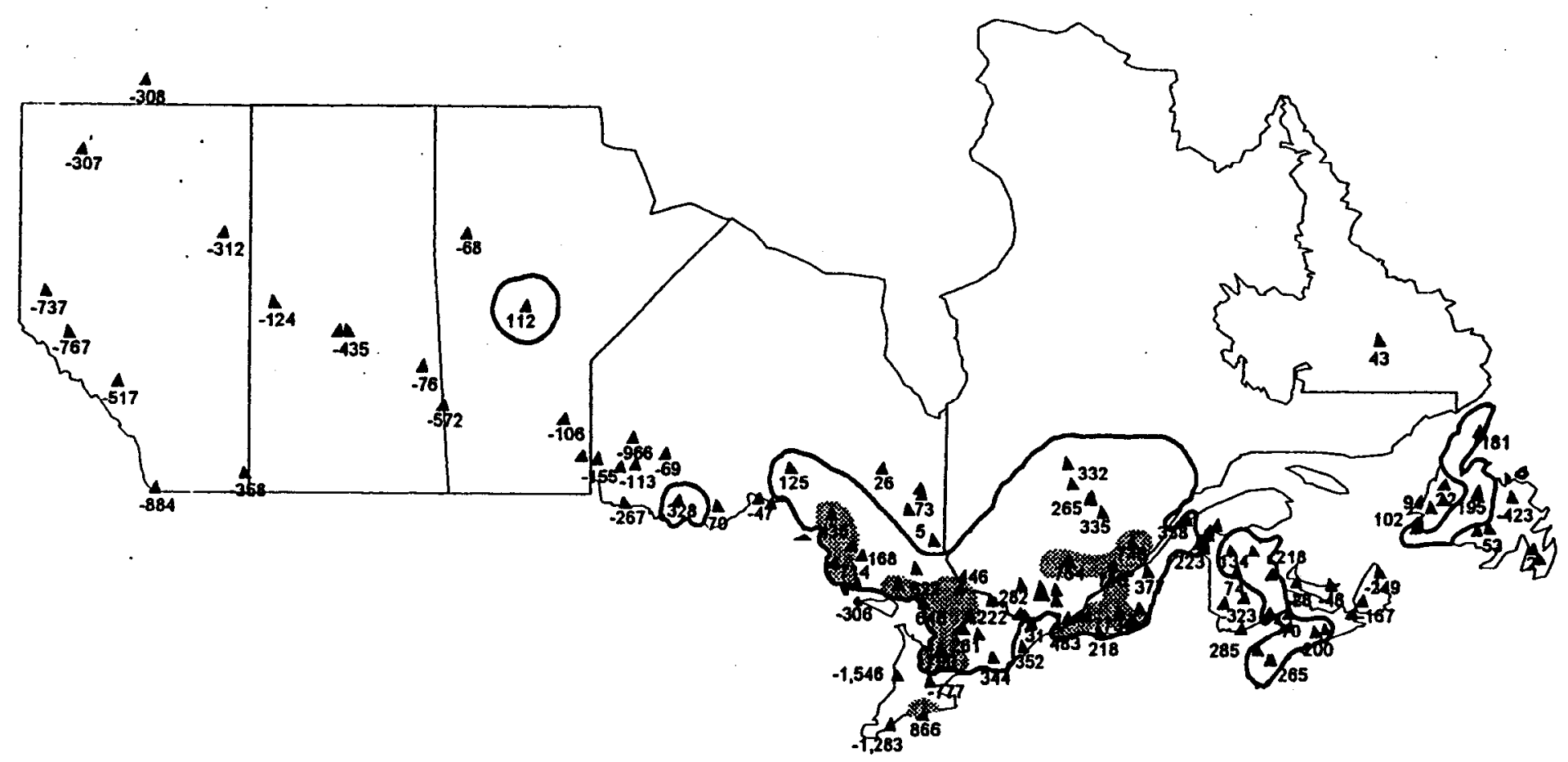


studies in sugar maple stands in Pennsylvania have demonstrated restoration of more vigorous growth and canopy health (Long et al., 1997). In some sugar maple soil systems efficient in retaining and recycling added nutrients, benefits of cation additions made to soils to offset nutrient imbalances may last several decades (Hendershot and Courchesne, 1994).

Sugar maple is also sensitive to changes in concentration of soil NO, and increasing $\mathrm{N}$ deposition to some $\mathrm{N}$-saturated forests is expected to cause nutrient imbalances, with resultant effects on growth (Yin et al., 1994). In addition despite the scientific and public focus on the role of acidic deposition, other co-occurring stressors of sugar maple forests may be equally important. The role of $\mathrm{O}_{3}$, for instance, has not been adequately investigated. Most of the sugar maple range (NAMP plot distribution) is located in areas of high seasonal ozone exposure and increases in canopy transparency have followed years with higher ozone levels, particularly in 1988 when SUM60 across the sugar maple range increased from 6,600 ppb hrs $\mathbf{O}_{3}$ to over 30,000 ppb hrs 0, (Pearson and Percy, 1997). Transparency also increased during 1988-1993 (Lachance et al., 1995) at those plots where $\mathrm{O}_{3}$ exceedances were highest. Visible foliar injury was reported on three indicator species at 59\%,34\% and 39\% of FHM plots in the region during 1994-1996 respectively (Stoyenoff et al., 1998).

In addition, winter damage from deep freezing of exposed soil and roots in 1980 in Quebec contributed to sugar maple decline and complicated symptom interpretation. Followup studies on sapflow changes following development of canopy dieback amplified by winter cold treatments of soil (Bertrand et al., 1996 and Robitaille et al., 1995) indicate that the degree of loss of root function may exceed estimates of damage to canopies based on visual symptomology. For example sapflow losses of 39\% were found on trees with only 9-13\% canopy losses (Robitaille et al., 1995). Such canopy losses have previously been considered normal for sugar maple, but may signal more substantive disruption of belowground processes.

During the early 1980's, the condition of paper birch (Betula papyrifera Marsh.) and mountain paper birch (Betula cordifolia Regel) growing along the Bay of Fundy coast in Canada also deteriorated significantly. Initial observations of Betula spp leafbrowning and premature abscission were recorded by the Forest Insect and Disease Survey (FIDS). Subsequent investigation excluded insects and diseases as causal agents. Atmospheric stressors were considered candidates, particularly acidic fog and $\mathbf{O}_{3}$ (Magasi, 1985).

Fogs were collected and found to deposit substantial amounts of acidity $(0.1-0.5 \mathrm{keq}$ ha"), which had not previously been detected and which exceeded amounts deposited to the same stands by rain. The fog exposure duration at a nearby site ranged up to $1400 \mathrm{hrs}$ (27\% of the time) during the growing season. Significant correlations were determined between $\mathrm{H}^{+}$ion $(\mathrm{P}<.001), \mathrm{NO}_{3}(\mathrm{P}<.001)$ concentrations and leaf browning (Figure 8). Continued investigation of the two taxa confirmed the relationship between fog frequency and foliar browning. All trees were affected during 1987-1990 followed by an apparent recovery in tree condition concurrent with historical (1915-1990) lows in fog frequency. Recovery was attributed to the shedding of dead branches and twigs during winter storms and the lack of initiation of new dieback due to low fog frequencies The lower taxon B. cordifoliu was found to be more prone to browning, slower to recover from dieback and more prone to mortality (Cox et al., 1996).

It has been known for some time that certain mid- to high-elevation species in the northeast like red spruce and balsam fir are adapted to cool, moist environments and are 


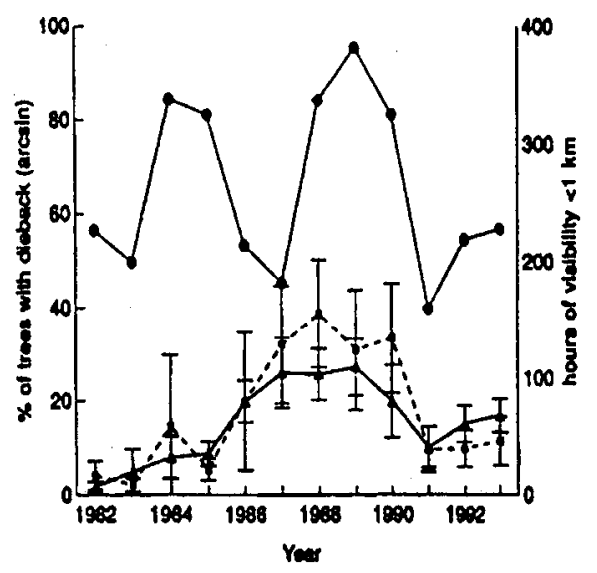

Figure 8. Percentage of Fundy coast B. cordifolia (A) and B. papyrifera ( $\mathbf{\square}$ ) trees with dieback symptoms in relation to hours of fog (visibility< $1 \mathrm{~km}$ ) $(\bullet)$ at the St. John airport from 1982 to 1993 . Reproduced from Cox $\boldsymbol{e}$ al. (1996).

immersed in clouds/fog for up to $44 \%$ of the growing season (Lovett et al., 1982; Schemenauer, 1986). Comparison of northeastern marine-corrected mountain cloud and coastal fog chemistries by Kimball et al. (1988) indicated coastal fogs were up to three times higher in ionic concentrations and were lower in $\mathrm{pH}$. NO, concentrations were especially high given the higher $\mathbf{O}_{\mathbf{3}}$ concentrations measured along the New England coast.

The potential for direct damage to vegetation from acid fog and cloud water is high and Maine coastal fogs have among the highest acidities (pH 2.8) ever recorded (Cape, 1993). When dry deposition is factored into total atmospheric deposition to birch leaf surfaces, very strong, localized acidities are likely (Wisiniewski, 1982), accentuated by meteorologicallydriven leaf surface wetting/drying cycles.

\section{Integrating Effects of Ambient Pollutant Levels on Forest Processes}

\subsection{EfFects on TREE PHYSIOLOGICAL PROCESSES}

Despite differences in species, levels and combination of principal and secondary stresses, and primary pathways of effects among the four case study forests, effects of air pollutants on the resources required for growth and defense are often similar. In Figure 9, changes in the primary resources that regulate forest function: carbon production and allocation, water supply, and plant nutrition are depicted. Important features and implications of alterations in these resources are discussed below.

\subsection{Effects on Carbon Production and Allocation}

Reduced photosynthetic production in response to chronic pollution stress was found in all four systems examined. This occurred both as a result of changes in photosynthetic rate per unit of foliage mass (a shift in biochemical production potential) as well as from changes in the amount of leaf area produced or retained under chronic pollution stress. The mechanisms of effect, and foliage age classes involved were quite different among the 
different forests, however. While premature loss of older needle classes has been observed with ozone exposures in both western and southern pine forests, loss of upper canopy foliage of northern hardwoods is most closely associated with nutrient depletion of the outer canopy due to both foliar leaching by acidic deposition, and reduced uptake of $\mathbf{C a}$ and magnesium from poorly buffered soils (Heisey, 1995; Ellsworth and Liu, 1994).

In red spruce significant loss of foliage can be caused by winter injury to current year needles, which are both the most productive and the most sensitive age class. Sensitivity is enhanced by exposure to mists at acidity levels that occur frequently at high elevation sites in the Eastern US, and has been linked to increased frequency of terminal shoot dieback (LeBlanc and Raynal, 1990, and see Figure 6). It is also associated with low Ca retention and is an apparent consequence of foliar leaching of membrane-associated Ca (DeHayes et al., 1997). Losses of foliar Ca by individual rain events may amount to $30 \%$ of the foliar Ca content (Joslin et al., 1988). Much slower loss rates have been estimated for sugar maple (lo-133 day half-life) suggesting biological non-significance (Scherbatskoy, 1989). However, Ca signaling in leaf physiological processes occurs at levels three to four orders of magnitude lower than those found in cell walls, and even small leaching losses from the small but active metabolic pools in foliage may significantly alter cell physiological functions (McLaughlin and Wimmer, 1999). Both reduced foliar Ca retention and reduced

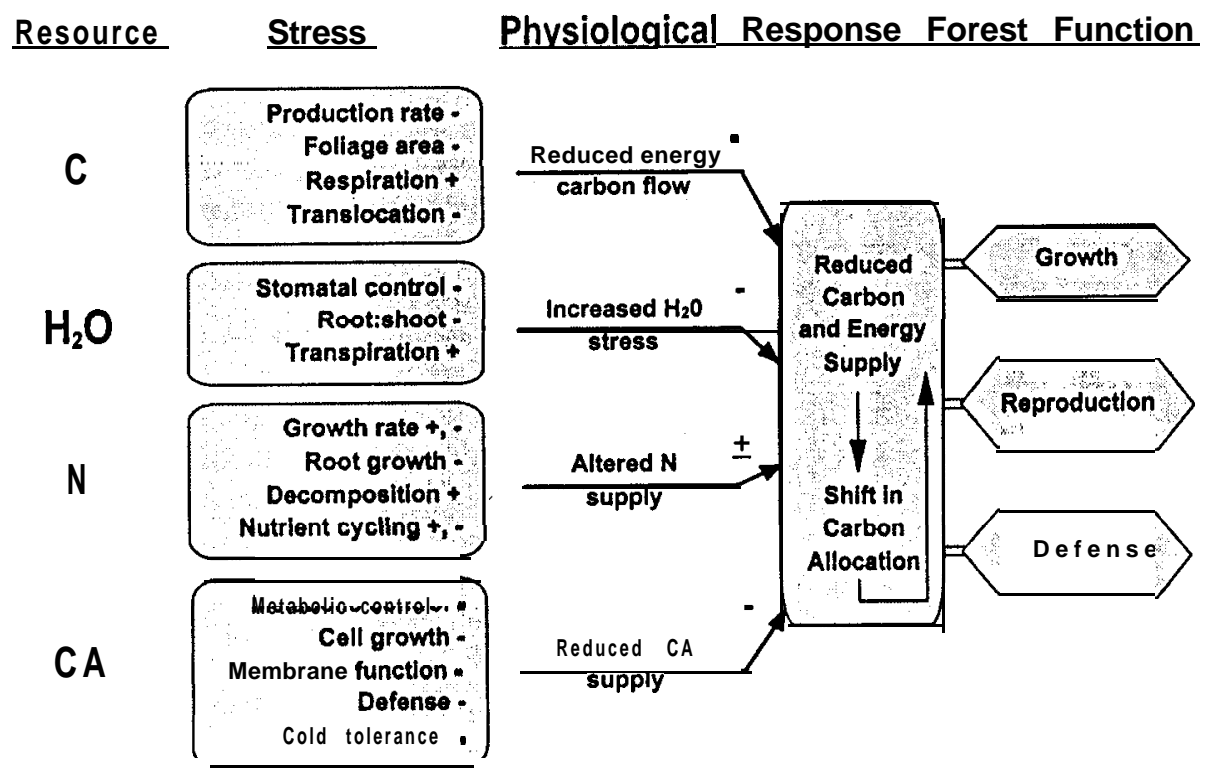

Figure 9. A summary of the physiological changes induced by ambient air pollution in the four case studies indicates multiple pathways of effects on carbon, water, and nutrient resources required for forest health. The net effect of these process-level effects has been multiple indications of reduced carbohydrate production by affected trees. Such changes typically lead to a shift in relative allocation of energy toward growth at the expense of reduced resistance to biotic and abiotic stresses. 
Ca supply rates from soil appear to contribute to reduced foliar $\mathbf{C a}$ and increased physiological dysfunction of red spruce foliage (McLaughlin and Kohut, 1992).

Both chronic $\mathrm{O}_{3}$ exposure of pines (Adams et al., 1990, McLaughlin et al., 1982) and exposure of red spruce to acidic deposition in the field (Andersen et al., 1991), reduce basipetal translocation of photosynthetically-fixed carbon from source foliage. Increased retention of photosynthate has also been associated with increased respiratory costs associated with repair of oxidant-stressed foliage and contributes to the reduced availability of carbohydrates for new growth (McLaughlin et al., 1982). Reduced foliar carbon production (reduced $\mathrm{Pn}$ rate and leaf area) and reduced allocation away from production centers leads to the reduced root growth frequently associated with ozone exposure (Cooley and Manning, 1987). By contrast the effects of acidic deposition on root growth and survival can occur both from reduced carbon production above ground (winter injury and increased respiration of foliage) as well as from toxicity associated with aluminum mobilization in the soil solution (Cronan and Grigal, 1995). More typically acidic deposition affects root growth by decreasing $\mathrm{Ca}: \mathrm{Al}$ ratios to levels which interfere with $\mathrm{Ca}$ uptake and impair root physiological function (Joslin et al., 1992, and Godbold and Kettner, 1991).

\subsubsection{Nutritional Effects of Changing $N$ and $C a$ Availability}

Changing nutrient availability induced by atmospheric deposition can also alter plant allocation of carbon in ways that increase sensitivity to other stresses. Such changes include increased deposition and accumulation of $\mathrm{N}$ (Aber et al., 1989), reduced deposition of atmospheric sources of $\mathrm{Ca}$ (Hedin et al., 1994), and reduced availability of Ca in soils (Likens et al., 1998). Increased absorption of atmospheric sources of $\mathrm{N}$ and metabolic utilization of $\mathrm{N}$ by forest canopies (Hanson and Lindberg, 1991, Fowler et al., 1998) as well as increasing $\mathrm{N}$ availability from chronic accumulation in surface soils has the effect of shifting tree growth and allocation of resources aboveground at a cost of reducing root mass and reducing root:shoot ratios (Persson and Madji, 1995, Schulze, 1989). Such changes can place forests at increasing risks of reduced uptake of water as well as other mineral nutrients.

$\mathrm{Ca}$, on the other hand, has a direct and indirect role in allocation of resources to defense and repair in plants as well as influencing respiratory metabolism. Availability of $\mathrm{Ca}$ is particularly important for developing plants because it is not translocated between plant organs and because it is required for a wide variety of metabolic functions associated with growth, structural integrity of cells and membranes, local and interorganismal signaling, and defense and repair processes associated with disease resistance (Hepler and Wayne, 1985). Ca supply is therefore linked to transpiration rate in trees and can be reduced by drought as well as factors which reduce root vitality. Accelerated leaching of $\mathrm{Ca}$ from foliage exposed to acidic mists (Joslin et al., 1988) and reduced availability of $\mathrm{Ca}$ in soil solutions in poorly-buffered soils exposed to strong anion inputs (Reuss and Johnson, 1986; Robarge and Johnson, 1992) can combine to limit Ca uptake and increase physiological stress in acidic soils.

\subsubsection{Altered water status}

Air pollution stress can increase water stress in forest trees by two principal pathways: alteration of transpiration through control of water flux from leaves at the membrane (substomatal) or stomatal level; or effects on water uptake related to changes in fine root biomass or root function. Much of our thinking regarding ozone and water stress has been 
based on seedling studies in which water stress has been shown to accelerate stomatal closure in response to high ozone exposures (Tingey and Hogsett, 1985). This assumption led Ollinger $\boldsymbol{e}$ t al. (1997) to assume a protective role of water stress in modeling growth responses of mature forests to ozone stress. However, in controlled studies with 3-yr-old beech trees the stomatal closure which occurred when well watered trees were exposed to ozone was impeded under dry conditions (Pearson and Mansfield, 1993) suggesting a more complex regulation of water loss under these conditions.

Larger forest trees typically have much lower ratios of leaf area to root mass than seedlings and have a larger stem volume which can provide an additional hydrologic reservoir during stress episodes (Kozlowski et al., 1991). While stomatal conductances of large trees of some western species can be much lower that for seedlings (Yoder et al. 1994, and Grulke and Miller, 1994), Samuelson and Kelly (1997) have reported both higher conductances and higher ozone uptake within the canopies of large trees than by nearby seedlings in Tennessee. The capacity for ozone to cause stomatal closure as a consequence of water stress may be reduced for larger trees at the moderate water stress levels which limit many physiological processes. Both cell wall growth and protein synthesis, for example, are reduced at stress levels well below those required to cause stomatal closure (Hsaio, 1973).

Studies in the field at ambient levels now provide direct and indirect evidence that moderate ozone levels can increase water stress and reduce growth in larger trees (see McLaughlin and Downing, 1997). Reduced stomatal control of water loss from conifers documented in European studies (Maeir- Maerker, 1997) documents one mechanism for this response, however reduced root function provides a potentially additive pathway that has not been adequately evaluated to date. On the other hand in the more arid San Berardino Forest, drought increased resistance of older needles to ozone induced injury. This suppression of $\mathrm{O}_{3}$ injury to older whorls of ponderosa and Jeffrey pines during drought years, was followed by $\mathrm{O}_{3}$ injury and needle abscission upon return of favorable soil moisture (Miller et al., 1996).

\subsection{EFFECTS ON BIOGEOCHEMICAL CYCLES}

The primary effects of current and projected future air pollutant loading on biogeochemical cycles and associated forest health are associated with three processes that operate concurrently in at least some soils in all of the four case studies we have examined. These include depletion of base cations due to increased mobilization and leaching from forest soils (Federer et al.,1989), alteration of nutrient availability in soil solutions through mobilization of acidic cations, AL, Fe, Mn, and H, (Robarge and Johnson, 1992 and Ulrich and Matzner, 1986), and finally the buildup of soil $\mathrm{N}$ to levels that saturate surface soils (Aber et al., 1989).

\subsubsection{Cation Losses}

Nutrient budgets for diverse forest stands now document the increased leaching of base cations associated with inputs of the strong anions $\mathrm{SO}_{4}$ and $\mathrm{NO}_{\mathrm{x}}$ to forest soils (Johnson et al. 1985; Federer et al., 1989; Johnson and Lindberg, 1992; Richter et al. 1994; Likens et al., 1996; and Likens et al., 1998). In general, acidic deposition has been found to approximately double leaching rates that occur naturally (Joslin et al., 1992 and Johnson and Todd, 1987) Long term depletion of base cations from both foliage and soils in the 
eastern US has led to accelerated depletion of exchangeable cations from mixed hardwood forested watersheds and predictions of Ca deficiency in coming decades (Federer et al., 1989). Similarly combined effects of forest growth, an important acidifying influence that is a natural part of cation accumulation by aggrading forests (Ulrich and Matzner, 1986), natural leaching and acidic deposition depleted $80 \%$ of the base cations from surface soils of a southern pine site in South Carolina over 30 years (Richter et al., 1994). Because of the importance of forest growth in accumulating $\mathrm{Ca}$ and other cations, whole tree harvesting, which removes nutrient rich branches as well as boles, can accelerate ecosystem depletion of cation pools (Federer et al., 1989).

\subsubsection{Acid Cation Interference}

Two properties of cation exchange in forest soils are pivotal to the capacity of acidic deposition to reduce physiological availability of cations: First, aluminum is mobilized more rapidly than $\mathrm{Ca}$ from exchange sites in the soil solutions when strong anions are deposited on poorly buffered soils (Reuss and Johnson, 1986); second strong binding capacity allows the acidic cations $\mathrm{Al}>\mathrm{Mn}>\mathrm{Fe}>\mathrm{H}$ to replace $\mathrm{Ca}$ and $\mathrm{Mg}$ from both physical and biological binding sites. The first property leads to domination of $\mathrm{Al}$ in soil solutions in high $\mathrm{N}$ and $\mathrm{S}$ deposition areas with poorly buffered soils. As $\mathrm{Ca}: \mathrm{Al}$ ratios fall below 1.0, a wide variety of studies indicate that the risk of adverse effects to forest physiological function increase (Cronan and Grigal, 1995). Analysis of tine root chemistry in both declining red spruce (Shortle and Smith, 1988) and declining sugar maple stands (Adams and Hutchinson, 1992) indicate that low Ca:Al levels in fine roots are associated with reduced growth of trees in poorly buffered soils.

The high replacement potential of acidic cations for $\mathrm{Ca}$, can result in displacement of this essential cation from the cell walls and membranes of tine roots resulting in and loss of membrane integrity and reduced root absorptive capacity (Zhao et al., 1987, Stienen and Bauch 1988 and Schroeder et al., 1988). In addition, Ca binding in cell walls, an important feature influencing the structural integrity of wood, can be reduced by acid cation substitution in xylem walls (Momoshima and Bondietti, 1990) thereby potentially reducing wood structural integrity (McLaughlin and Wimmer, 1999).

\subsubsection{Nitrogen saturation}

The long-term inputs of atmospheric sources of $\mathrm{N}$ to forest soils have begun to produce measurable changes in forest $\mathrm{N}$ cycles in industrialized regions. The phenomenon of $\mathrm{N}$ saturation occurs when availability of ammonium and nitrate is soils exceeds the combined plant and microbial demands (Aber et al., 1989; Schulze, 1989). This process can occur naturally where $\mathrm{N}$-fixing species dominate (Cole, 1992), but in other forest types it results from the combined addition of $\leq 40 \mathrm{~kg} \mathrm{ha}^{-1} \mathrm{y}^{-1}$ of anthropogenic $\mathrm{N}$ added to the 20-75 $\mathrm{kg} / \mathrm{ha} / \mathrm{y}$ produced annually by decomposition processes of coniferous forests and $\mathbf{5 0 -}$ $175 \mathrm{~kg} / \mathrm{ha} / \mathrm{y}$ similarly produced by deciduous forests (Aber et al., 1989). Based on European studies Schulze et al. (1989) have suggested critical loading thresholds for N of 3-14 $\mathrm{kg} \mathrm{ha}^{-1}$ $\mathbf{y}^{-1}$ for poorly buffered soils and 3-48 kg ha-' $\mathbf{y}^{-1}$ for calcareous soils (note current wet deposition loading patterns for North America in Figure 3).

The net effect of $\mathrm{N}$ saturation is accumulation of the acidic nitrate ion in the soil profile, reduced $\mathrm{Ca}: \mathrm{Al}$ ratios in soil solutions, reduced root mass and depth, and increased $\mathrm{N}$ export to streams. Evidences of $\mathrm{N}$ saturation are now becoming apparent in many different forest types including high elevation Southern Appalachian spruce-fir (Nodvin et al., 1995), mid-elevation mixed hardwoods in North Carolina (Swank and Vose, 1997), 
West Virginia (Gilliam et al., 1996), Northern Hardwoods in both the US (Aber et al.,1989, and Likens et al. 1998) and Canada (Foster et al., 1992) as well as in areas of regionally high N deposition in California (Bytnerowicz and Fenn 1996). Nitrogen saturation has implications for long term stability of forest nutrient cycles because it can lead to breakdown of the cation- rich 0 horizon, and increased leaching of cations from deeper soil horizons (Shortle and Bondietti, 1992). Evidence suggests that the low soil Ca resulting from this process, affects root function, including uptake of $\mathrm{N}$, thereby potentially contributing further to $\mathrm{N}$ accumulation in the soil (McLaughlin and Wimmer, 1999). Under these conditions forests can be expected to become increasingly dependent on recent litter for required $\mathrm{Ca}$ levels and roots to colonize shallower soil layers in the forest floor (Persson and Madji, 1995 and Joslin and Wolf, 1992). Another consequence of increasing $\mathrm{N}$ can be reduced growth of fine roots (Dougherty et al., 1997).

\subsubsection{Combined Effects on Forest Nutrient Cycling}

So how significant are these combined processes in limiting nutrient availability to regional forests? Both comparative nutrient budgets across diverse forest types (Johnson and Lindberg, 1992) as well as variations in foliar and root nutrient levels across environmental gradients (Friedland et al., 1988; Robarge at al., 1989; and Joslin et al., 1994) indicate that there are significant differences in plant-available nutrients, particularly the base cations, $\mathrm{Ca}$ and $\mathrm{Mg}$ associated with gradients in acidic deposition to forests. The Integrated Forest Study (IFS, Johnson and Lindberg, 1992) has provided nutrient budgets for at least two representatives for three of the four forest types we have addressed in this review. In Figure 10, we compare for spruce-fir, southern pines, and northern hardwoods, the distribution of $\mathrm{Ca}$ pools in vegetation, the forest floor, and soil exchangeable pools (Figure 10a) with the fluxes of $\mathrm{Ca}$, including $\mathrm{Ca}$ uptake, leaching, and net increment (Figure 10b). These comparisons emphasize the large differences in nutrient capital both between and within systems, and they also demonstrate why the risks of acidic deposition to nutrient cycles can differ markedly within regions and behveen forest types. The lower exchangeable Ca pools at high elevation spruce fir forests (in both the Southern (GSM) and Northern (WF) Appalachian Mountains are readily apparent from these contrasts.

Long-term biomass modeling based on critical load exceedance calculations has predicted that forest productivity will decline in some regions with continued SO, and NO, deposition (Arp and Oja, 1992). Long-term (30 yrs) ecosystem research at Hubbard Brook, $\mathrm{NH}$ reported by Likens et al. (1996) has documented substantial losses of soil base cations due to acidic deposition. Important consequences for forest sustainability are predicted. Long-term research at the watershed level has also been instrumental in documenting SO, flux through nutrient-poor sugar maple forests indicating that soil buffering capacity of these forests has been depleted. On the other hand, there is also evidence at the watershed scale that reducing $\mathrm{S}$ emissions in the Northeastern US is beginning to have measurable effects of nutrient cycles of some forests. For example, at Turkey Lakes Watershed in central Ontario, monitoring of precipitation, nutrient cycling and streamflow chemistries from five basins has detected declining acidic concentrations in precipitation during 19811990 and this has resulted in lower concentrations in soil runoff and stream water. Decreases of up to $31 \%$ have reduced the flux of SO, in the soil (Foster and Hazlett, 1991), and will reduce rates of cation loss from these systems.

Foliar and fine root nutrient analyses provide the most important integrators of nutrient availability to forests. Analysis of foliar nutrient data suggest that foliar cation levels principally $\mathrm{Ca}$ and $\mathrm{Mg}$ are currently in the range of expected deficiency symptoms at wide 


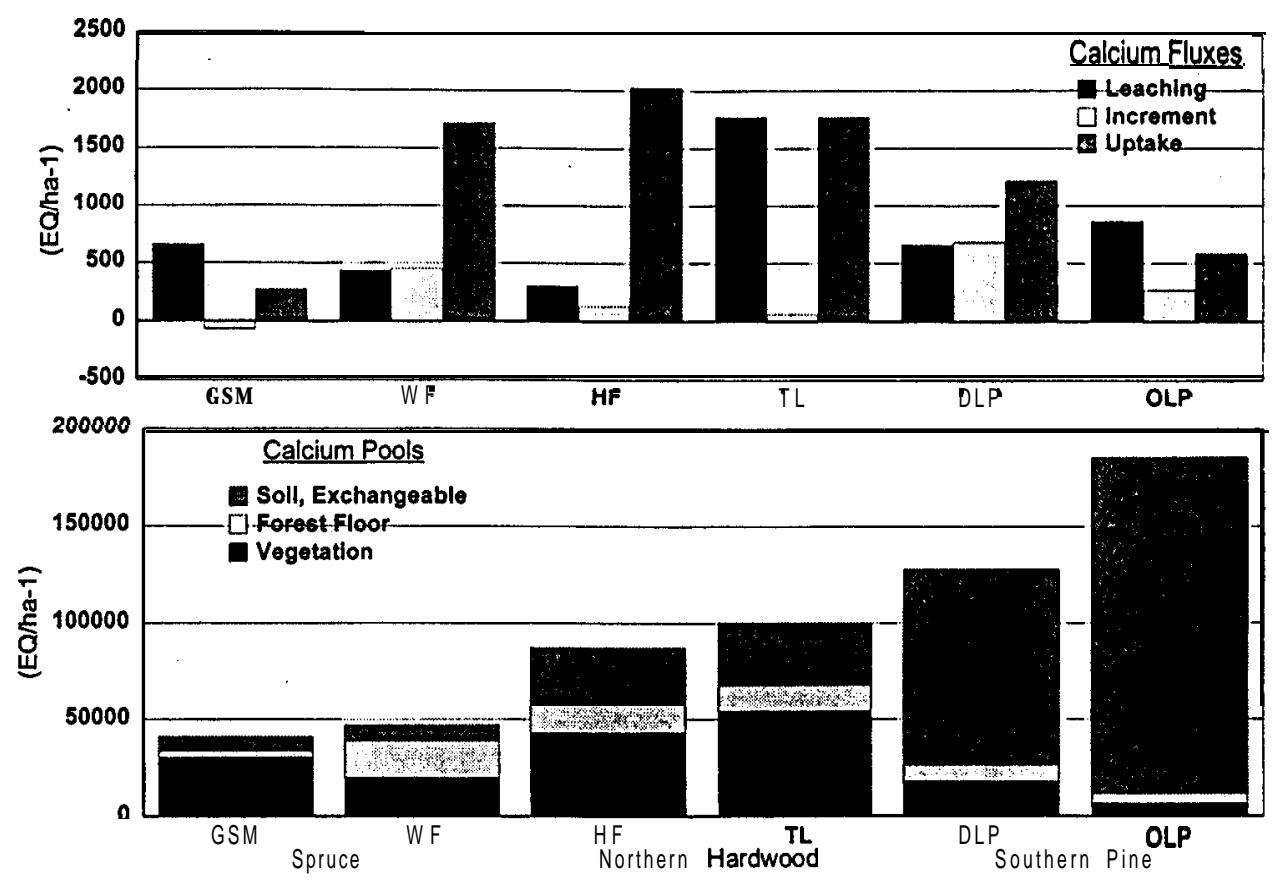

Figure 10. Comparative $\mathrm{Ca}$ fluxes (a) and pools (b) for representative spruce, northeastern hardwood, and pine forests are important components of differences in sensitivity of these forests to acidic deposition (after Johnson, 1992). Forest types include: high elevation spruce-fir forests, Great Smoky Mountains (GSM) in TN, and Whiteface Mountain (WF) in New York; northern hardwood forests, Huntington Forest (HF) in NY and Turkey Lakes (TL) in Ontario; and southern loblolly pine forests in Durham, NC (Duke Forest (DF) and Oak Ridge, TN (OLP). Note the low net increment (a) and lower exchangeable soil pools (b) for high elevation spruce and northern hardwood forests compared to managed lowland pine forests

spread locations in the high elevation spruce fir forests (Friedland et al., 1988, Joslin et al., 1994). Reduced base cation levels have also been noted at higher elevations for the northeastern hardwood forest at Hubbard Brook (Likens et al., 1998). Such data do not distinguish the relative roles of innately low soil fertility and any additive effects of acidic deposition on foliar nutrient uptake. However several lines of evidence suggest that acidic deposition had been an important contributing factor to reduced cation availability in areas of high atmospheric deposition: These include (1) accelerated leaching of base cations from foliage by acidic rain and mist events (Joslin et al., 1988), (2) demonstrated physiological significance of relative small changes in the small, active pools of leaf Ca (McLaughlin et al., 1993 and DeHayes et al., 1997) ; (3) close linkages observed between input of SO, and $\mathrm{NO}$, elevated levels of $\mathrm{Al}$ in soil solutions and depression of $\mathrm{Ca}: \mathrm{Al}$ ratios in soil solutions to levels (seasonal $\mathrm{Ca}: \mathrm{Al}$ mean $=0.40$, Johnson et al., 1991) at which cation uptake by roots is inhibited; (4) shifting patterns of cation content of annual tree rings that indicate that substitution of acid cations for basic cations has occurred in recent decades in areas 
receiving high deposition of atmospheric acids (Bondietti et al., 1989, Bondietti et al., 1990, and see Watmough, 1997); and finally, (5) Retrospective analysis of foliar cation levels at a Southern Appalachian spruce/fir site, which indicates that foliar levels of $\mathrm{Mg}$ and Ca have decreased by 50\% and 33\% respectively during the past twenty years (Shepard $\boldsymbol{e t}$ al. 1995).

\section{Implications of Changes in Forest Processes for Forest Health}

From the utilitarian perspective the direct effects of air pollution on forest health that can be documented at present on North American forests may be considered to be relatively small compared to documentable effects of other types of stresses, such as fire and biotic diseases '(see Table II). The most direct linkages can be made to the regional forest types we have chosen as case studies. With red spruce, sugar maple, white birch, and western pines, all predominantly older growth natural communities, the symptoms are reduced growth, weakened trees, increased susceptibility to stresses, and increased mortality. These are the classical indicators of the multicomponent decline complex in which air pollution can be a contributing factor (Manion, 1981). In two of the four systems, northeastern montane red spruce and southwestern pines in the San Bernardino forest, decreasing health had been translated into changes in stand structure and diminished basal area, meeting the utilitarian definition of health loss. With southern pines, a substantial component of which is managed commercial forest, data from controlled chamber studies, dendroecological studies, and models (see Table III) indicate that growth of mature pines is being reduced by current typical ambient ozone levels at annual rates that may vary from 0 to $10 \%$ per year. However, at present there are no indications of community-level changes attributable to ozone, and the biological effects of cation depletion of southern pine soils on health of these forests are still conjectural (NAPAP, 1998).

From the ecological perspective, however, we must ask how the process-level indicators of altered forest function from these few case studies relate to responses of these and other forest types to the range of biotic and abiotic stresses that normally regulate forest growth and development. In Figure 9 we summarized relationships among processes affected by ambient levels of air pollutants and changes in water, carbon, and nutrient resources that can be documented at those levels. These are of course the same media through which climate, competition, and disease affect forest processes and forest health. In the regional forest environment it is important to recognize that chronic stress from air pollution can only be expressed through altered sensitivity of forest physiological processes to natural biotic and abiotic stresses. Additionally, internal shifts in resource allocation strategies related to plant allometry (McLaughlin and Sliriner, 1980), stage of growth (Mooney and Chu, 1974), nutrition (Clancy et al., 1995) age (Waring, 1987), species type (Waring and Cobb, 1992) and stand level nutrient balance (Mattson and Addy, 1975) significantly influence plant allocation of resources among the competing demands of growth, defense, and reproduction and hence can alter forest sensitivity to insects and diseases.

Evidence from process level studies indicates that regional levels of air pollution stress measured in our case study forests are reducing carbon reserves, increasing water stress, and reducing nutrient availability. Carbon (energy) reserves are critical to plant defenses in many ways, including notably formation of defense chemicals that prevent damage and repair or replacement of damaged tissues after attack. The allocation of carbon to defense 
in forest trees is a much lower priority than maintaining leaf and root function (Waring and Pittman, 1985), thus chemical and structural defenses may be more significantly reduced at the organ or whole tree level by stresses which reduce carbohydrate production levels. Root diseases of conifers, including littleleafdisease (Phytophtera cinnamomia) of shortleaf pine (Hepting, 1945) and Armillerea root rot (Wargo, 1972) which often develop as secondary pathogens following predisposing stresses (Manion, 1981) are enhanced by reduced carbohydrate supply to roots. The increased sensitivity of ponderosa pine to bark beetle attack in the San Bernardino Mountains following $\mathbf{O}_{\mathbf{3}}$ damage is a classical case of reduced defenses of forest trees being related to chronic air pollution stress (Cobb et al., 1968).

Closely tied to reduced carbohydrate reserves, whatever the cause, is reduced root growth and function and ultimately increased water stress. Water stress frequently increases tree sensitivity to insect attack (Clancy et al., 1995) although sensitivity can vary with level of stress (Lorio and Summers, 1986) and species type (Waring and Cobb, 1992). For example, susceptibility of conifers to insect herbivores was consistently increased by water stress (29 out of 31 studies) whereas broadleaves showed almost equal positive and negative responses (Waring and Cobb, 1992).

Significant strides in understanding the interplay of plant physiological responses to stress have come in the area of plant nutrition, specifically significantly expanded understanding of the role of $\mathrm{Ca}$ in regulating a wide range of physiological processes. These include intercellular and intraorganismic signaling (McAinsh and Hetherington, 1998 and Trewavas and Malho,1997), chemical defenses (Pooviah, 1988 and Roberts and Harmon, 1992), and physical repair of cellual damage by disease (Dixon and Harrison, 1994). In addition to being essential for cell wall growth (Eklund and Eliasson, 1990), lignin is an important defense chemical against diseases such as damage to firs by the balsam wooley adelgid (Timmel et al., 1986). Poor soil nutrition, including low $\mathrm{Ca}, \mathrm{P}, \mathrm{K}$, and $\mathrm{Mg}$ has been recognized as a predisposing factor is sensitivity of Douglas fir to spruce budworm attack (Kemp and Moody, 1984). Stark (1965) lists 20 studies in which forest fertilization increases resistance of pines to insect attacks. Interestingly in 10 of 12 studies in which $\mathrm{Ca}$ was added alone or as a component of fertilization, reduced density or increased mortality of insect larvae was noted. Radiochemical studies suggest that $\mathrm{Ca}$ may be toxic to insects (see Stark, 1965). The loss and/ or reduced availability of exchangeable soil Ca from soil reserves in response to long term deposition of $\mathrm{S}$ and $\mathrm{N}$, thus has important implications for long term forest growth and forest ecosystem health.

Collectively the physiological effects of air pollutants would be anticipated to either predispose forest trees to other stresses, or amplify their negative effects. Only recently, have patterns of change over time ( $>10$ yrs) at regional and national scales been statistically analyzed with the vigor required to attribute changes in forest health at the species level to individual and/or complexes of biotic and abiotic stressors, including air pollutants (Brandt et al., 1999). For example, in North America the regional patterns of most frequent occurrence of major disease problems documented by forest surveys, are spatially consistent with the patterns of highest levels of ozone and acidic deposition as noted in Figure 11. Such a relationship is compatible with the role of strong anion deposition in depleting available pools of cations, notably $\mathrm{Ca}$, from the relatively low soil pools in some Northeastern forests (see Figure 10). This supports the possibility that both carbohydrates and nutrient resources that influence forest health through altering tree resistance or recovery potential are relatively more affected by pollution stress in the same areas that insects and disease are apparently most problematic. Detailed statistical analyses might 
reveal a statistical relationship between developmental trends and air quality that is beyond the scope of the more qualitative analyses presented here. While such patterns complicate analyses of cause and effect relationships on a regional basis, they also provide opportunities to examine component stresses from the perspective of process-level interactions involving carbon, water, and nutrient resources. Such analyses would be required to permit more robust tests of cause and effect relationships.
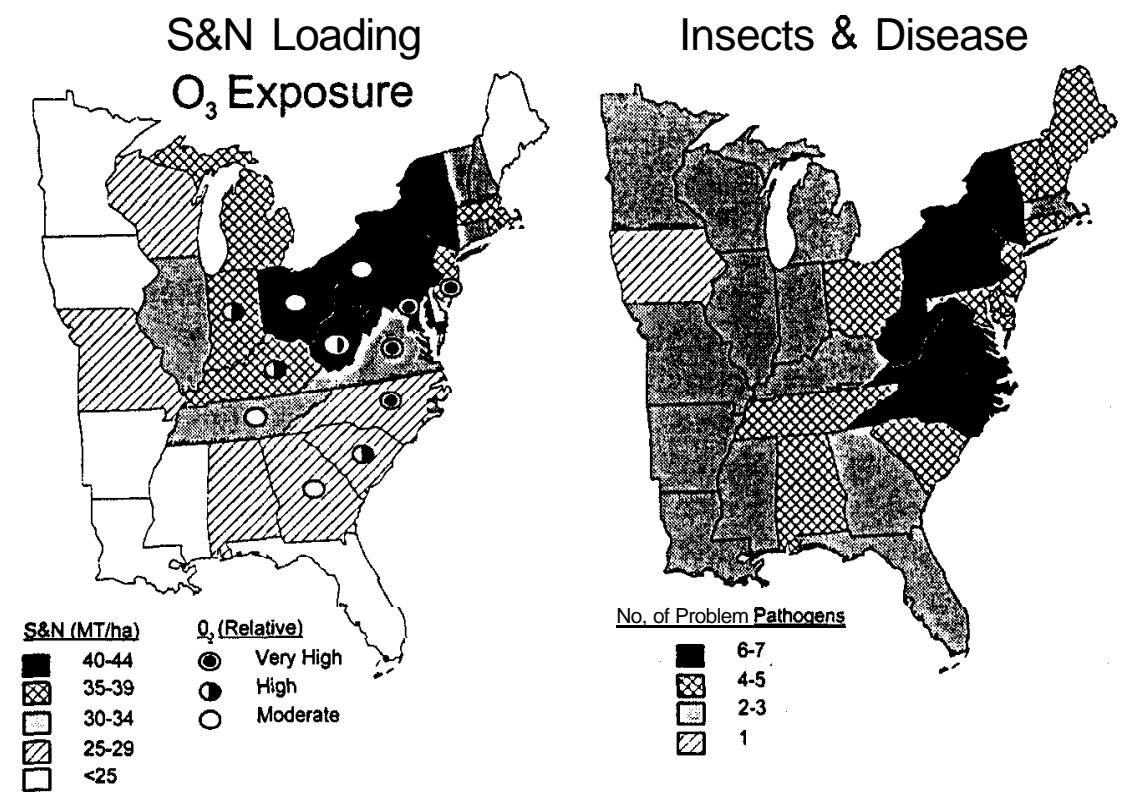

Figure 11. The areas of the eastern US that currently have the greatest frequency of problems from Forest insects and disease (USDA, 1997) also receive the highest deposition of $\mathbf{S}$ and $\mathbf{N}$, and/or have the highest annual exposure to tropospheric ozone. Deposition data are area-integrated esttimates at a state level from regional isopleths presented by Allen and Gholz (1995) based on summed wet deposition of S and $\mathrm{N}$ in $\mathrm{kg} / \mathrm{ha} / \mathrm{y}$ and relative ozone exposure For 1998-1999. The area-integrated ozone exposure index was $>850$ for states in the very high category, 775-850 For the high category and 700-775 For the moderate category. By contrast, exposure indices For AL, ME, and IO were 500,280, and 120, respectively.

\section{Predicted Changes in Physical Climate and Effects on Forest Physiological Function}

The linkages between changing global atmospheric chemistry and climate change have become solidified in recent years (Thomson, 1995, IPCC, 1998). On a global scale, temperatures are predicted to increase by $1-3.5^{\circ} \mathrm{C}$ by 2100 . Spatial and temporal patterns

of precipitation are expected to change more variably, leading to increasing frequency of droughts in some regions. Stratospheric ozone depletion since 1980 is not predicted to recover until 2050, even under the most optimistic scenario (Madronich et al., 1995). Resultant increases in biologically-effective ultraviolet radiation (UV-B, 280-315 nm) reaching forests may have important consequences for tree molecular biology (DNA), biochemistry, physiology, growth, regeneration and reproduction (Percy and Gordon, 1998) 
as well as changes in plant succession and biodiversity (SCOPE, 1992). Ecological systems, including notably forests, are predicted to be significantly impacted by both the magnitude and variability of climatic shifts produced (IPCC, 1998). These responses, which include both positive and negative physiological effects that will influence process level changes induced by regional air pollutants, are reviewed very briefly below. Primary emphasis is on results from the Southeastern US, where an integrated series of studies has recently been completed (Mickler and Fox, 1997).

From a physiological perspective, the effects of increasing $\mathrm{CO}_{2}$ and increasing temperature on net primary production, the effects of temperature on the frequency and severity of drought, and the effects of increasing $\mathrm{N}$ on nutrient uptake and allocation to shoots and leaching from soils appear to be the most compelling components of climate change that could significantly influence forest sensitivity to biotic and abiotic stresses. Predicted regional climate models for the Southeastern US associated with a doubling of $\mathrm{CO}_{2}$ levels (Cooter, 1998), include a mean growing season temperature increase of $3.7-6.4^{\circ} \mathrm{C}$ with more variable and less certain effects on precipitation patterns.

A wide variety of controlled studies now indicate that increasing $\mathrm{CO}_{2}$ will lead to significant increases in leaf photosynthetic rates and increased net primary production of forest trees (Wullschleger et al., 1997; Teskey et al., 1998; and Norby et al., 1999). Although very limited data are available for more mature forest trees, results to date suggest that positive responses are rather robust, in terms of absence of limitations by variations in supply of other resources (Wullschleger et al., 1997). Increasing temperature, on the other hand, affects many essential forest processes and in many different ways. Most notably the carbohydrate economy may be improved by extending the length of the growing season, but adversely impacted by the increased respiratory costs of temperature-driven metabolic processes. A $5^{\circ} \mathrm{C}$ temperature increase might increase dark respiration by $50 \%\left(\mathrm{Q}_{10}=2\right)$ and have a major impact on carbohydrate production and allocation. Based on branch studies, Teskey et al. (1998) found that a $2^{\circ} \mathrm{C}$ temperature increase, while it increased $\mathrm{Pn}$ at ambient $\mathrm{CO}_{2}$, reduced the Pn response to increasing $\mathrm{CO}_{2}$. In addition increasing temperature will increase evapotranspiration, thereby increasing potential limitations of water supply on the amount and allocation of growth (Sclulze et al., 1987).

Current global models used for predicting the distribution and condition of forests in response to global change (IPCC, 1998), consider increases in $\mathrm{CO}_{2}$ and water availability, on forest growth, but, at present, do not consider potential implications of regional air pollutants on forest growth processes. Modeling results, for a $2 \mathrm{X} \mathrm{CO}_{2}$ scenario (Table IV) indicate that with climatic warming the potential forest cover in North America might increase by $24 \%$ (without) to $44 \%$ (with) $\mathrm{CO}_{2}$ stimulation of growth. However, results from field chamber experiments provide evidence of the potential for $\mathrm{O}_{3}$ and $\mathrm{CO}$, co-exposure to offset predicted gains from elevated $\mathrm{CO}_{2}$ and to enhance damage from $\mathrm{O}_{3}$ (Kull et al., 1996) and indicate a need for consideration of combined effects of these gases in future assessments.

Much of the simulated increases in Table IV occur as a result of increases in the distribution of temperate forests, which migrate northward, decreasing forest area in the conterminous USA and increasing potential forest cover in Canada and Alaska. By contrast, the modeling projects a significant increase in areas within each forest type in which declining growth would be expected, with 9 to $19 \%$ of the area being so affected if the positive effects of $\mathrm{CO}_{2}$ are unconstrained. In the absence of positive $\mathrm{CO}_{2}$ effects, climate change caused predicted productivity to decline over $45 \%$ to $89 \%$ of the total forested areas of North America. 
TABLE IV

Predicted percentages of current forested area in North America that would lose or gain biomass with a doubling of preindustrial atmospheric $\mathrm{CO}_{2}$ levels. The effects of associated climate change without $\mathrm{CO}$, potential physiological benefits of $2 \times \mathrm{CO}_{2}$ are shown in the numerator of each response pair. ${ }^{1}$

PERCENTAGE OF FORESTED AREA RESPONDING $\left(-1+\mathrm{CO}_{2}\right)$

\begin{tabular}{|c|c|c|}
\hline & Biomass loss $(-1+)$ & Biomass gain $(-1+t)$ \\
\hline Boreal forest end Taiga tundra & $25 / 5$ & $49 / 83$ \\
\hline Boreal Conifer & $84 / 16$ & $2 / 54$ \\
\hline Temperate evergreen forest & $55 / 8$ & $12 / 66$ \\
\hline Temperate mixed forest & $44 / 4$ & $26 / 95$ \\
\hline
\end{tabular}

'Source: IPCC (1998), The Regional Impacts of Climate Change. These are considered conservative estimates of expected temperature effects due to delayed temperature equilibration to increasing $\mathbf{C O}_{2}$ (WCC, 1998). Total forest area predictions for North America are for a 42-44\% gain with CO, end 21-24\% gain in the absence of CO, effects.

The physiological basis of the IPCC (1998) model-predicted declines in forest health in the two times ambient $\mathrm{CO}_{2}$ environment are based upon the effects of high temperatures on forest growth, and associated increases in drought, fire, and pathogens. In reality the spectrum of responses is likely to include both positive and negative responses in forest growth over time and across regions depending on the rate of change of the various climatic components and spatial variability in soils. In regional simulation of responses of loblolly pine stands to climate change in the Southeastern US (McNulty et al., 1996), small increases in temperature $\left(2^{\circ} \mathrm{C}\right)$ were found to have positive effects on Pn unless combined with reduced water supply. Non-linearity of expected responses is particularly likely in the case of $\mathrm{N}$ deposition (Aber et al., 1989), which is envisioned to have initial stimulatory effects on forest growth on N-poor soils, such as for southern pines, followed by negative effects as cation depletion continues, leading potentially to $\mathrm{N}$ saturation.

Stimulation of growth regionally by $\mathrm{N}$ deposition, as has apparently occurred in some areas of Europe in recent decades (Sterba, 1996), also has potential parallel non-linear effects on global climate change. Modeling studies indicate that $\mathrm{N}$-stimulation of growth in a $\mathrm{CO}$,-enriched environment could initially lead to significantly increased carbon and $\mathrm{N}$ storage in the soils, but at the risk of forests ultimately behaving as sources of $\mathrm{NO}_{2}$ from microbial release of accumulated N (Norby, 1998 and Goulding et al., 1998). The effects of warming on litter decomposition and release of accumulated nitrate represent an additional risk, particularly to N-saturated soils such as occur in the high elevation sprucefir ecosystem (Joslin, and Johnson, 1997). Interestingly studies in Germany indicate that liming can drastically reduce $\mathrm{N}_{2} \mathrm{O}$ release from forest soils fertilized by $\mathrm{N}$ (Brumme and Beese, 1992) a response that suggests important linkages between $\mathrm{Ca}$ depletion from soils and the ability of vegetation to utilize/retain added or excess soil $\mathrm{N}$.

\section{Synthesis and Recommendations}

The case studies we have reviewed indicate that stress from regional scale air pollutants is affecting the physiological processes of forest tree species within diverse, widely distributed, 
and regionally important forests. The processes affected and the stresses they produce are important to the way these forests grow and respond to biotic and abiotic stresses within their regional environments. If one measures forest health strictly in utilitarian terms, the level of effects to the near term economic health of the forests we have examined that can be clearly linked to specific effects of air pollutants may be considered small relative to the total suite of stress responses that affect forest health. However, If one views the potential importance of the processes affected in terms of implications for performance of these species within the framework of biotic and abiotic stresses that affect and are affected by the same resources, the potential ecological effects become potentially much larger, particularly over time. In this regard we consider the potential to be high for ambient ozone and acidic deposition stress to enhance the effects of drought, insects, disease, and high temperature in many situations, but to vary widely across the forest landscape just as these stresses vary. Similar conclusions have been reached in a synthesis of European physiological studies, which highlighted changes in carbohydrate production and allocation as critical to enhanced sensitivity of European forests to secondary stresses (Skarby et al., 1998).

The well documented effects of ambient air pollutants on carbohydrate production and allocation, root growth, water uptake and control, and soil $\mathrm{Ca}$ and $\mathrm{N}$ levels indicate that regional atmospheric pollution could significantly enhance the adverse effects of global warming, particularly in the United States. While we expect increasing $\mathbf{C O}_{2}$ to ameliorate air pollution effects on tree physiology by enhancing carbohydrate production and allocation to roots, biochemical interactions at the leaf level are less clear (Kull et al., 1996). We expect the effects of increased temperature and increasing drought coupled with the concurrent effects of ozone, and acidic deposition (including $\mathrm{N}$ ) on root vigor and root depth to increasingly place limitations on $\mathrm{CO}_{2}$ induced enhancement of growth. Under these conditions, the enhancement of stress from drought, disease, and tire associated with climatic warming become more likely and the potential for interactions among the physical and chemical climate would be increased. Also to be considered in this mix are future trends in air pollutants. Reductions in S deposition are already underway and signal a measurable reduction in regional $S$ deposition (Likens et al., 1996). Predictions of future ozone levels depend not only on levels of $\mathrm{N}$ emissions, but also on regional climate, which will affect regional air patterns and the extent to which forests serve as sources for NOx and volatile organic carbon. Current predictions for future ozone levels vary widely from likely reduced levels based on expected trends in N emissions (EPA, 1997) to increases of $30 \%$ in the next 25 years (NAS, 1992).

\subsection{FUTURE MONITORING NEEDS}

As Innes (1998) points out, despite the fact that most countries do not attribute damage to air pollutants, considerable care must be taken as absence of record may not mean that the particular cause of injury (e.g. air pollution) was not present. Development of better diagnostic techniques applicable to regional/national/multinational inventories of crown transparency and discoloration remain to be developed (Ferretti, 1998; Innes, 1998). The very nature of effects of chronic air pollution on forest ecological processes assures that attribution of causal relationships between air pollution and forest health will be very difficult without at least annual scale data on changes in system function, Because the carbon, water, and nutrient resources affected by air pollution are affected by many other stresses, it has required multidisciplinary team approaches to couple focused process level 
studies aimed at documenting mechanisms of response with the patterns of change detected by survey approaches. The case studies we have presented indicate the value of designing surveys that consider both ecological and pollution gradients and make comparisons across ecologically analogous sites that tie in to hypothesized mechanisms of action. Such a gradient approach was developed by Legge $\boldsymbol{e t}$ al. $(198$ 1) around a point source. It is now implemented in the "CFS Forest Indicators of Global Change Project" using sugar maple, white pine and red spruce ARNEWS/NAMP plots, with on-site process research, across gradients $(2000 \mathrm{~km})$ in acid deposition exceedance, $\mathrm{O}_{3}$ exceedance and climate (temp. precip.) in eastern Canada.

Because of the temporal covariances among stressors in the environment, the development of a time series of multiple component environmental data provides an analytical framework within which to identity and model dominant independent variable and their interactions in affecting observed responses. As an example, the development of dendroecology as a method to evaluate annual variability in forest growth responses to physical and chemical climate has provided important tools to identify shifts in climategrowth relationships indicative of the timing and magnitude of increased external stresses, such as regional air pollution (McLaughlin et al., 1987, Zahner et al., 1989; Cook and Johnson, 1989, Petersen et al., 1995). The development of additional analytical approaches such as multispectral scanning, which can be deployed with remote sensing technology, offers important new tools to obtain repeated measures of changes in canopy condition (Royle and Lathrop, 1997), canopy chemical changes such as lignin content indicative of soil nitrification rates (Wessman et al., 1989), as well as providing indicators of more subtle shifts in leaf physiology, such as changes in photosynthesis and stomatal conductance (Carter, 1994) in response to environmental change. The statistical power provided by repeated measures of forest responses at interannual to annual scales can help provide important insights into the roles of both primary and secondary variables in controlling forest growth responses in a changing chemical and physical climate. This is substantiated by the retrospective statistical analysis of ARNEWS tree mortality (1985-1996) in relation to acidic deposition and other abiotic and biotic factors (Brandt et al., 1999).

While we have focused primarily on physiological changes in this review, the development of quantitative indicators of tree condition also has great value in delineation of areas with outward evidences of changing forest health and mapping changes in those areas over time. Merging of monitoring and research expertise at the working levels will give impetus to the development, and implementation of more sensitive, cause-attributable diagnostic indicators. Successful examples of this concept in practice can now be found in both Europe (Swiss Federal Institute for Forest, Snow, and Landscape Research, Birmensdorf), and North America (Canadian Forest Service, Forest Health Network). In the past, monitoring and process-level research programs have tended to operate in parallel However, monitoring data must be fully integrated with process studies if we are to more fully understand the influence of air pollutants and climate change on our forest health and long-term sustainability. The San Bernardino case study (Miller and McBride, 1998) remains the model of such a systematic approach to forest health.

In conclusion, our analyses indicate that changes in depth and vigor of root systems, shifts in pool sizes and allocation patterns of carbon, and changes in supply rates of $\mathrm{N}$ and $\mathrm{Ca}$ represent important shifts in ecological function that are currently occurring in diverse forest types across North America. The influence of these process level changes on future health of North American forests could be substantially increased in coming decades if projected changes in climate become a reality. Under such conditions, evaluating the 
diverse influences of multiple stresses, operating in multiple combinations, will require monitoring programs that combine economic and ecological indicators of forest health (Olsen and Schreuder, 1997). Future monitoring programs should address multiple interactive hypotheses for causality with analytical tools that can adequately evaluate consistency, responsiveness, and mechanistic linkages of cause effect relationships across gradients in resource supply, both natural and manipulated. Such efforts should help forest ecologists to manage resources of North American forests in the future in ways that enhance both ecological and economic health.

\section{References}

Aber, J. D., Nadelhoffer, K. J., Steudler, P., Melillo, J. M.: 1989, BioScience 39, 378.

Adams, C. M.. and Hutchinson, T. C.: 1992, Can. J. For. Res. 22, 1489.

Adams, H. S., Stevenson, S. L., Blasing, T. I., Duvick, D. N.: 1985, Env. Exp. Bot. 25,315.

Adams, M. B., Edwards, N. T., Taylor, G. E., Jr., Skaggs, B. L.: 1990, Can. J. For. Res. $20,152$.

Allen, E.R. and Gholz, H.L.:1995, in S. Fox and RA. Mickler (eds), Impacts of Air Pollutants on Southern Pine Forests, Springer, New York, p 83.

Amundson, R. G., Hadley, J. L., Fincher, J. F., Fellows, S., Alscher, R. G.: 1992, Can. J. For. Res. 22, 1605.

Andersen, C. P., McLaughlin, S. B., Roy, W. K.: 1991, Can. J. For. Res. 21, 455-461.

Arbaugh, M. J., Miller, P. R., Carroll, J. J.: 1998, Envir. Pollut. 101,291.

Arp, P.A. and Oja, T.: 1992, CEA No. 841-726, Joint CEA-CPPA-FC-EC Project Tech. Rep. Part Xvl.

Arp, P.A., Oja, T., March, M.: 1996, Can. J. For. Res. 26,696.

Bangerth, F.: 1979, Ann. Rev. Phytopathol.17, 97.

Barnard, J., Lucier, A. A., Johnson, A. H., Brooks, R T., Kamosky, D. F., Dunn, P. H.: 1990, NAPAP State of Science and Technology, National Precipitation Assessment Program.

Bartholomay, G. A., Eckert, R T, Smith, K. T.: 1997, Can. J. For. Res. 27,361.

Beattie, B. L. and Whelpdale, D. M.: 1989, Water Air Soil Pollut. 46, 45.

Bemier, B. And Brazeau, M.: 1988a, Can. J. For. Res., 18,754.

Bemier, B., and Brazeau, M.: 1988b, Can. J..For. Res. 18,762.

Bemier, M., Pare, D., Brazeau, M.: 1989, Water, Air Soil Pollut. 48,239.

Bertrand, A., Robitaille, G., Boutin, R., Nadeau, P.: 1996, Tree Physiol. 15, 775.

Bertrand, A., Robitaille, G., Nadeau, P.,Boutin, R.: 1994, Tree Physiol. 14, 413.

Binkley, D., Driscoll, C. T., Allen, H. L., Schoenenberger, P. and McAvoy, D.: 1989, Acid deposition andforest soils: context and case studies in the Southeastern United States, Springer-Verlag Ecological Studies 77.

Bondietti, E. A., Baes, C. F. III, McLaughlin, S. B.: 1989, Can. J. For. Res. 19,586.

Bondietti, E. A., Momoshima, N., Shortle, W. C., Smith, K. T.: 1990, Can. J. For. Res. 20, 1850.

Brandt, J. P., Tomm, B. D., Hurley, J. E.: 1999, Water Air Soil Pollut. (submitted).

Brook, J. R.: 1995, Atmos. Environ. 29, 1795.

Brumme, R. and Beese, F.: 1992, J. Geophysical Res. 97, $12,851$.

Bytnerowicz, A., and Fenn, M.: 1996, Environ. Pollut, 92, 127.

Bytnerowicz, A., Percy, K., Riechers, Padgett, P., Krywult, M.: 1998, Chemos. 36: 697. 
Cape, J.N.: 1993, Environ. Pollut. 82, 167.

Carter, G. A.: 1994, Znt. J. Remote Sensing 15,697.

Chappelka, A. H. and Samuelson, L. J.: 1998, New Phytol. 139, 49.

Clancy, K. M., Wagner, M. R, Reich, P. B.: 1995, pp. 118-180 in W. K. Smith and T. M. Hinckley (eds.), Ecophysiology of Coniferous Forests, Academic Press.

Clarkson, D. T. and Hanson, J. B.: 1980,Ann. Rev. Plant Physiol. 31,239.

Cobb, F. W., and Stark, R W.: 1970, J. For. 68, 147.

Cobb, F. W., Wood, D. L., Stark, R W., Parameter, J. R: 1968, Hilgardia 39, 141.

Cole, D. W.: 1992, Atmospheric Deposition and Forest Nutrient Cycling, Springer-Verlag. pp. 150-151.

Cook, E. R and Johnson, A. H.: 1989, Water, Air, Soil Pollut. 48,127.

Cook, E. R and Zedaker, S. M.: 1992, pp. 192-23 1 in C. Eagar and M. B. Adams, Ecology and Decline of Red Spruce in the Eastern United States, Springer-Verlag.

Cooley, D. R and Manning, W. J.: 1987, Envir. Pollut. 47, 95.

Cooter, E. J.: 1998, pp. 15-54 in R. A. Mickler and S. Fox, The Productivity and Sustainability of Southern Forest Ecosystems in a Changing Environment. SpringerVerlag.

Cox, R.M., Lemieux, G., Lodin, M.: 1996, Can. J. For. Res., 26,682.

Cronan, C. S. and Grigal, D. F.: 1995, J. Envir. Qual. 24,209.

Davidson, A.: 1993, Air Waste 43, 226.

DeFelice, T. T.: 1997, Atm. Res. 43,325.

DeHayes, D. H., Thornton, F. C., Waite, C. E., Ingle, M. A.: 1991, Can. J. For. Res. 21 , 1292.

DeHayes, D. H.: 1992, pp. 295-337 in C. Eagar and M. B. Adams, Ecology and decline of red spruce in the eastern United States. Springer-V\&lag.

DeHayes, D. H., Schaberg, P. G., Hawley, G. J., Borer, C. H., Cumming, J. R, Strimbeck, G. R.: 1997, Tree Physiol. 17,687.

DeHayes, D. H., Schaberg, P. G., Hawley, G. J., Strimbeck, G. R.: 1999, Bioscience (in review).

D'Eon, S. P., and Power, M.: 1989, The Acid Rain National Early Warning System (ARNEWS) Plot Network, Forestry Canada Inf. Report PI-X-91, Petawawa.

D'Eon, S. P., Magasi, L. P., Lachance, D., DesRochers, P.: 1994, Canada's National Forest Health Monitoring Plot Network: Manual on Plot Establishment and Monitoring (Revised), Can. For. Serv. Inf. Rep. PI-X-1 17, Petawawa..

Dixon, R. A. and Harrison, M. J.: 1994, Annu. Rev. Phytopathol. 32,479.

Dougherty, P. M., Allen, H. L., Kress, L. W., Mm-thy, R., Maier, C. A., Albaugh, T. J., Sampson, D. A.: 1997, pp. 149-168 in R. A. Mickler and S. Fox, The Productivity and Sustainability of Southern Forest Ecosystems in a Changing Environment. SpringerVerlag.

Dougherty, P. M., Teskey, R. O., Jarvis, P. G.: 1992, pp. 303-312 in R. B. Flagler (ed.), Transactions: The Response of Southern Commercial Forests to Air Pollution. Air and Waste Management Association.

Dull, C. W., Ward, J. D., Brown, H. D., Ryan, G. W., Clerke, W. H., Uhler, R J.: 1988, Evaluation of spruce and fir mortality in the southern Appalachian mountains. USDA Forest Service Southern Region R8-PR 13. 92 pp.

Eagar, C.: 1984, The Southern Appalachian Spruce-Fir Ecosystem: Its Biology and Threats, National Park Service, Research/Resources Management Report SER-71. 
Eagar, C. and Adams, M. B.: 1992, Ecology and Decline of Red Spruce in the Eastern United States. Springer-Verlag. pp. 295.

Eklund, L., and Eliasson, L.: 1990, J. Exp. Bot. 41,863.

Ellsworth, D. S. and Liu, X.: 1994, Can. J. For. Res. 24, 2118.

Environment Canada (EC):1997. Canadian Acid Rain Assessment Vol. 2: Atmospheric Science Assessement Report., Ottowa.

EPA: 1996, National Air Quality and Emissions Trends Report, 1995. EPA 454/R-96-005.

EPA: 1997, National Air Pollutant Emission Trends, 1900-1906, U.S. Environmental Protection Agency EPA-454/R-97-011.

EPA: 1998, National Air Quality and Emissions Trends Report, 1996. EPA 454/R-97-013.

Federer, C., Hombeck, J. W., Tritton, L. M., Martin, C. W., Pierce, R S., Smith, C. T.: 1989, Environ, Manage. 13,000.

Ferretti, M.: 1998, Chemos. 36, 1031.

Flagler, R. B., Brissette J. C., Bamett, J. P.: 1997, pp. 73-92 in R A. Mickler and S. Fox, The Productivity and Sustainability of Southern Forest Ecosystems in a Changing Environment. Springer-Verlag.

Foster, N. W. and Hazlett, P.W.: 1991, pp. 179-191 In Acid Deposition. Origins, Impacts and Abatement Strategies, Springer-Verlag.

Foster, N. W., Morrison, I. K., Yin, X. and Arp, P. A.: 1992, Can. J. For. Res. 22, 1753.

Fowler, D., Flechard, C., Skiba, U., Coyle, M. and Cape, J. N.: 1998, New Phytol. 139, 11.

Fox, S. and Mickler, R. A.: 1995, Impact of Air Pollutants on Southern Pine Forests. Springer-Verlag.

Fraser, G. A., Phillips, W. E., Lamble, G. L., Hogan, G. D., Teskey, A. G.: 1985, Can. For. Ser, Rep. E-X-36. 43 p.

Friedland, A. J., Gregory, R. A., Karenlampi, L., Johnson, A. H.: 1984, Can. J. For. Res. Friedland, A. J., Hawley, G. J., Gregory, R A.: 1988, Plant Soil 105,189.

Fujioka, F. M., Roads, J. O., Chen, S. C.: 1998, Climatology, in Miller, P. R and McBride, J. (eds.), Oxidant Air Pollution Impacts in the Montane Forests of Southern California: The San Bernardino Case Study, Springer-Verlag, Heidelberg (in press).

Gilliam, F. S., Adams, M. B., Yurish, B. M.: 1996, Can. J. For. Res. 26, 196.

Godbold, D. L. and Kettner, C.: 1991, J. Plant Physiol. 138, 231.

Goulding, K.W.T., Bailey, N. J., Bradbury, N. J., Hargreaves, P., Howe, M., Murphy, D. V., Poulton, P. R., Willison, T. W.: 1998, New Phytol. 139, 49.

Grissino-Mayer, H. D. and Butler, D. R: 1993, Southeast. Geogr. 1, 65.

Grulke, N. E. and Miller, P. R.: 1994, Tree Physiol. 14,659.

Hall, J. P.: 1995, For. Chron. 71,607.

Hall, J. P. and Addison, P. A.: 1991, Response to air pollution: ARNEWS assesses the health of Canada's forests, For. Can. Sci. Dir. Inf. Rep. DPC-X-34, Ottawa, 42 PP.

Hall, J. P., Bowers, W., Hirvonen, H., Hogan, G., Foster, N., Morrison, I., Percy, K., Cox, R., Arp, P.: 1997, 1997 Canadian Acid Rain Assessment: Vol. 4 The Effects on Canada's Forests, Natural Resources Canada, 47 pp.

Hanson, P. J. and Lindberg, S. E.: 1991, Atmos. Envir. 25, 1615.

Hendershot, W. W.: 1991, Fert. Res. 27, 63.

Hendershot, W. W. and Courchesne, F.: 1994, Can. J. For. Res., 24,609.

Hedin, L. O., Granat, L., Likens, G. E., Bulshand, T. A., Galloway, J. N., Butler, T. J., Rodhe, H.: 1994, Nature 367,351.

Heisey, R. M.: 1995, Water Air Soil Poll. 82,675. 
Hepler, P, K., and Wayne, R 0.: 1985, Ann. Rev. Plant Physiol. 36,397.

Hepting, G. H.: 1945, Phytopath. 35, 106.

Hertel, G. D. and McKinney-McNeal: 1991, USDA For, Serv. Agric. Inf. Bull. 622, 19.

Hinckley, T., Ford, D., Segura, G., Sprugel, D.: 1992, Key processes from stand to tree level in Wall, G. (ed.), Implications of climate change for Pacific Northwest Forest Management. University of Waterloo, Department of Geography paper 15, Waterloo, pp. 33-43.

Hoffer, T. E., Miller, D. J., Farber, R J.: 1981, Atmos. Environ. 15, 1935.

Hogsett, W. E., Herstrom, A. A., Laurence, J. A., Lee, E. H., Weber, J. E., Tingey, D. T.: 1993, Proceedings of the $\mathbf{4}^{\text {th }}$ US/Dutch International Symposium: Comparative Risk Analysis and Priority Setting for Air Pollution Issues. Air and Waste Management Association.

Hsaio, T. C.: 1973, Ann. Rev. Plant Physiol. 24,519.

Innes, J. L.: 1993, Forest Health: Its Assessment and Status, CAB International, 677 pp. Innes, J. L.: 1998, Chemos. 36, 1025.

Intergovernmental Panel on Climate Change (IPCC): 1998, The Regional Impacts of Climate Change. An Assessment of Vulnerability. pp. 267-279 in R T. Watson, M. C. Zinyowooa, R. H. Moss, and D. J. Dokken (eds.), Cambridge University Press.

Jagels, R.: 1986, I.A. WA. Bull., 299.

Jeffries, D. S. (ed.): 1997, 1997 Canadian Acid Rain Assessment: Vol. 3 Aquatic Effects. Environment Canada, Burlington.

Jenkins, A. F.: 1997, J. For.

Johnson, A. H. and Siccama, T. G.: 1983, Envir. Sci. Technol. 17, 294A.

Johnson, A. H., Mclaughlin, S. B., Adams, M. B., Cook, E. R, DeHayes, D. H., Eager, C., Femandez, I. J., Johnson, D. W., Kohut, R J., Mohnen, V. A., Nicholas, N. S., Peart, D. R., Schier, G. A., White, P. S.: 1992, pp. 385-411 in C. Eagar and M. B. Adams, Ecology and Decline of Red Spruce in the Eastern United States. Springer-Verlag.

Johnson, D. W. and Todd, D. E.: 1987, Plant Soil 102, 99.

Johnson, D. W. and Lindberg, S. E.: 1992, Atmospheric deposition andforest nutrient cycling. Springer-Verlag.

Johnson, D. W., Richter, D. D., Lovett, G. M., Lindberg, S. E.: 1985, Can. J. For. Res. 15, 773.

Johnson, D. W., Van Miegroet, H., Lindberg, S. E., Todd, D. E., Harrison, R B.: 1991, Can. J. For. Res. 21,769.

Joslin, J. D., McDuffie, C. M., Brewer, P. F.: 1988, Water, Air, and Soil Pollut.' 39,355.

Joslin, J. D. and Wolfe, M. H.: 1992, Can. J. For. Res. 22, 893.

Joslin, J. D. and Wolfe, M. H.: 1994, Soil Sci. Soc. Am. J. 58, 1572.

Joslin, J. D., Kelly, J. M., Van Miegroet, H.: 1992, J. Env. Qual. 21, 12.

Joslin, J. D., and Johnson, J. W.: 1997, pp. 571-590 in R A. Mickler and S. Fox, The Productivity and Sustainability of Southern Forest Ecosystems in a Changing Environment. Springer-Verlag.

Joslin, J. D., Wolfe, M. H., Garten, C. T.: 1998, pp. 557-570 in R A. Mickler and S. Fox (eds.), The Productivity and Sustainability of Southern Forest Ecosystems in a Changing Environment. Springer-Verlag.

Kemp, W. P. and Moody, U. L.: 1984, Environ. Entomol. 13, 1291.

Kimball, K. D., Jagels, R., Gordon, G. A., Weathers, K. C., Carlsile, J.: 1988, Water Air Soil Pollut. 39,383. 
Kolb, W. E. et al.: 1994, J. For. 92, 10.

Kozlowski, T. T., Kramer, P. J., Pallardy. S. G.: 1991, The Physiological Ecology of Woody Plants, Academic Press.

Kress, L. W., Allen, H. L., Mudano, J. E., Stow, T. K. : 1992, Environ. Toxicol. Chem. 11, 1115.

Kull, O., Sober, A., Coleman, M. D., Dickson, R E., Isebrands, J. G., Gagnon, Z., Karnosky, D. F.: 1996, Can. J. For. Res. 26,639.

Lachance, D., Hopkin, A, Pendrel, B., Hall, J. P.: 1995, Health of Sugar Maple in Canada: results from the North American Maple Project, 1988-1993, Canadian Forest Service Report ST-X-10, 27 pp.

LeBlanc, D. C. and Raynal, D. J.: 1990, Can. J. For. Res. $20,1415$.

Lee, W. S., Chevone, B. I., Seiler, J. R: 1990, Water Air Soil Pollut. 51, 105.

Legge, A. H., Jaques, D. R, Harvey, G. W., Krouse, H. R, Brown H. M., Rhodes, E. C., Nosal, M., Schelhase, H. U., Amundson, R G., Walker, R. B.: 1981, Water Air Soil Pollut. 15, 77.

Likens, G. E., Driscoll, C. T., Buso, D. C.: 1996, Science 272,244.

Likens, G. E., Driscoll, C. T., Buso, D. C., Siccama, T. G., Johnson, C. E., Lovett, G. M., Fahey, T. J., Reiners, W. A., Ryan, D. F., Martin, C. W., Bailey, S. W.: 1998, Biogeochem. 41, 89.

Long, R P., Horsley, S. B., and Lija.: 1997, Can. J. For. Res. 27, 1560.

Lorio, P. L., Jr. and Sommers, R A.: 1986, Tree Physiol. 2,301.

Lovett, G. M., Reiners, W. A., Olson, R K.: 1982, Science 218, 1303.

Madronich, S., McKenzie, R L., Caldwell, M., Bjom, L. 0.: 1995, Ambio 24, 143.

Magasi, L. P.: 1985, Forest pest conditions in the Maritimes in 1985, Can. For. Sev. Inf. Rep. M-X-159, Fredericton.

Maier-Maercker, U.: 1997, Trees 11,229.

Maier-Maercker, U. and Koch W.: 1992, Trees 7, 12.

Manion, P. D.: 1981, Tree Disease Concepts, Englewood Cliffs, NY, Prentice Hall.

Mattson, W. J. and Addy, N. D.: 1975, Science 190,515.

McAinsh, M. R. and Hetherington, A. M.: 1998, Perspectives 3, 22.

McLaughlin, S. B.: 1985, J. Air Poll. Control Assoc. 35,516.

McLaughlin, S. B., McConathy, R K., Duvick, D., Mann, L. K.: 1982, For. Sci. $28,60$.

McLaughlin, S. B. and Shriner, D. S.: 1980, Plant Disease Vol. 5. Academic Press. pp. 407-431.

McLaughlin, S. B. and Downing, D. J.: 1996, Can. J. For. Res. 26,670.

McLaughlin, S. B. and Downing, D. J.: 1997, pp. 207-230 in R. A. Mickler and S. Fox (eds.), The Productivity and Sustainability of Southern Forest Ecosystems in a Changing Environment. Springer-Verlag.

McLaughlin, S. B., Downing, D.J., Blasing, T. J., Cook, E. R, Adams, H. S.: 1987, Oecologia 72,487.

McLaughlin, S. B., Andersen, C. P., Edwards, N. T., Roy, W. K., Layton, P. A.: 1990, Can. J. For. Res. 20,485.

McLaughlin, S. B., Andersen, C. P., Hanson, P. J., Tjoelker, M. G., Roy, W. K.: 1991, Can. J. For. Res. 21, 1234.

McLaughlin, S. B., Tjoelker, M. G., Roy, W. K.: 1993, Can. J. For. Res. 23,380.

McLaughlin, S. B. and Kohut, R: 1992, pp. 338-384 in C. Eagar and M. B. Adams (eds.), Ecology and Decline of Red Spruce in the Eastern United States. Springer-Verlag. 
McLaughlin, S. B., Joslin, J. D., Robarge, W., Stone, A., Wimmer, R, Wullschleger, S. D.: 1998, pp. 255-277 in R A. Mickler and S. Fox (eds.), The Productivity and Sustainability of Southern Forest Ecosystems in a Changing Environment. SpringerVerlag.

McLaughlin, S. B. and Wimmer, R: 1999, New Phytologist (in press).

McNulty, S. G., Vose, J. M., Swank, W. T.: 1996, Ambio 25,449.

Mickler, R and Fox, S.: 1997, The Productivity and Sustainability of Southern Forest Ecosystems in a Changing Environment. Springer-Verlag.

Miller, P. R.: 1992, Mixed conifer forests of the San Bernardino Mountains in Olson, R K., Binkley, D., Bohm, M. (eds.), The Response of Western Forests to Air Pollution, Springer-Verlag, New York. Pp. 461-497.

Miller, P. R.: 1973, pp. 101-117 in J. A. Naegele, Air Pollution Damage to Vegetation. Advances in Chemistry Series 112. Am. Chem. Soc., Washington.

Miller, P. R., Chow, J., Watson, J. G.: 1996, Assessment of Acidic Deposition and Ozone Effects on Conifer Forests in the San Bernardino Mountains, California Air Resources Board Report.

Miller, I., Lachance, D., Burkmann, W. G., Allen, D.C.: 1991, North American maple decline project: organization and field methods, USDA Forest service Gen. Tech. Rep. NE-154,

Miller, P. R. and McBride, J. (eds.): 1998, Oxidant Air Pollution Impacts in the Montane Forests of Southern California: The San Bernardino Case Study, Springer-Verlag, Heidelberg.

Miller, P. R., McBride, J. R., Schilling, S. L., Gomez, A. P.: 1989, pp. 309-324 in R K.

Olson and A. S. Lefohn, Effects of Air Pollution on Western Forests. Air and Waste Manage. Assoc., Pittsburgh.

Miller, P.R., and Millecan, A.A.: 1971, Plant Disease Rep. 55, 555.

Miller, P. R., Pat-meter, J. R, Taylor, 0. C., Cardiff, E. A.: 1963, Phytopath 53, 1072.

Miller, P. R., Chow, J., Watson, J. (eds.): 1996, Assessment of Acidic Deposition and Ozone Effects on Conifer Forests in the San Bernardino Mountains, California Air Resources Board Report NTIS 97115612, Sacremento.

Miller, P. R., Taylor, 0. C., Wilhour, R G.: 1982, Oxidant air pollution effects on a western coniferous forest ecosystem. US EPA Report No. EPA-600/D-82-276.

Millers, I., Lachance, D., Burkman, W. G., Allen, D. C.: 1991, North American Sugar Maple Decline Project: Organization and FieldMethods. U.S. Dep. Agric. For. Serv., Radnor.

Molnnen, V. A.: 1992, pp. 64-124 in C. Eagar and M. B. Adams (eds.), Ecology and Decline of Red Spruce in the Eastern United States. Springer-Verlag.

Momoshima, N. and Bondietti, E. A.: 1990, Can. J. For. Res. 20, 1840.

Mooney, H. A. and Chu, C.: 1974, Oecologia 14,295.

Morrison, I.K., Fournier, R.E., Hopkin, AA.: 1996, Proceedings $16^{\text {th }}$ IUFRO International Meeting for Specialists in Air Pollutant Effects on Forest Ecosystems, Fredericton, 402 pp.

NAPAP: 1990, National Acid Precipitation Assessment Program, State of Science/Technology. Report Series.

NAPAP: 1998, National Acid Precipitation Assessment Program Biennial Report to Congress: An Integrated Assessment, Silver Spring, MD. 
NAS: 1992, Rethinking the Ozone Problem in Urban and Regional Air Pollution. National Academy of Sciences. National Research Council. National Academy Press. 500 pp.

Natural Resources Canada (NRCAN).: 1996, 1995 Compendium of Canadian Forestry Statistics. Canadian Council of Forest Ministers, Ottawa. 202 pp.

Natural Resources Canada (NRCAN).: 1997, 1996 Compendium of Canadian Forestry Statistics. Canadian Council of Forest Ministers, Ottawa. 234 pp.

Natural Resources Canada (NRCAN).: 1998, The State of Canada's Forests, 109 pp.

Nicholas, N. S.: 1992, Stand Structure, Growth, and Mortality in Southern Appalachian Spruce-Fir. Ph.D. Dissertation, Virginia Polytechnic Institute and State University, 176 pp.

Nodvin, S. C., Van Miegroet, H., Lindberg, S. E., Nicholas, N. S., Johnson, D. W.: 1995, Water, Air, and Soil Pollut. 85, 1647.

Norby, R J.: 1998, New Phytol. 139, 189.

Norby, R J., Wullschleger, S. D., Gunderson, C. A., Johnson, D. W., Ceulemans, R: 1999, Plant Soil Envir. 22, (in press),

O'Laughlin, J., Livingston, R. L., Thier, R., Thornton, J., Toweill, D. E., Morelan, L.: 1994, J. Sust. For. 2, 65.

Olivotto, C. (ed.): 1997, Canadian 1996 Nox/VOC Science Assessment: Summary for Policy Makers, Environment Canada, Toronto.

Ollinger, S. V., Aber, J. D., Reich, P. B.: 1997, Ecol. Appl. 7, 1521.

Olsen, A. R and Schreuder, H. T.: 1997, Envir. Ecol. Stat. 4, 167.

Olson, R. K.: 1992, Physiography of forest types in Olson, R K., Binkley, D. and Bohm, M. (eds.), The Responses of Western Forests to Air Pollution, Springer-Verlag, New York. pp. 7-40.

Ouimet, R. and Fortin, J.-M.: 1992, Can. J.. For. Res. 22,699.

Peart, D. R., Nicholas, N. S., Zedaker, S. M., Miller-Weeks, M., Siccama, T. G.: 1992, pp. 125-191 in C. Eagar and M. B. Adams (eds.), Ecology and Decline of Red Spruce in the Eastern United States, Springer-Verlag.

Pearson, M. and Mansfield, T. A.: 1993, New Phytologist 123,351.

Pearson, R. G. and Percy, K. E.: 1990, The 1990 Canadian Long-range Transport of Air Pollutants and Acid Deposition Assessment Report: part 5 Terrestrial Effects, Federal/Provincial Research and Monitoring Coordinating Committee (RMCC), 105 pp.

Pearson, R. G. and Percy, K. E.: 1997, Canadian 1996 NO $/$ /VOC Science Assessment: Report of the Vegetation Objective Working Group. Canadian Council of Ministers of Environment (CCME) Multistakeholder NO $/$ VOC Science Plan, pp.

Percy, K. E. and Gordon, D. C.: 1998, W-B and Canada's Forests: State of Science and Risk. Pp 75-85 in Legge, A. H. and L.L. Jones (ed.), Proceedings Air and Waste Management Association Speciality Conference on Emerging Air Issues for the 21" Century, Calgary

Percy, K. E., Jagels, R., Marden, S., McLaughlin, C. K., Carlisle, J.: 1993,. Can. J. For. Res. 23, 1472.

Persson, H. and Majdi, H.: 1995, Water, Air, and Soil Pollut. 85, 1287.

Peterson, D. L., Silsbee, D. G., Poth, M., Arbaugh, J., Biles, F. E.: 1995, J. Air Waste Manage. Assoc. 45, 36.

Peterson, D. L., Arbaugh, M. J., Robinson, L. J.: 1991, Holoc. 1, 50.

Pooviah, B. W.: 1988, Senescence and Aging in Plants, Academic Press, Inc. 
Powell, D. S., Faulkner, J. L., Darr, D. R, Zhu, Z., MacCleery, D. W.: 1992, Forest Resources of the United States. USDA Forest Service Gen. Tech Report RM-234,132 pp.

Prinz, B.: 1987, Environment 29,10.

Pronos, J., Vogler, D. R, Smith, R S.: 1978, An evaluation of ozone injury to pines in the southern Sierra Nevada. USDA Forest Service Forest Pest Management Report 78-1, San Francisco.

Rehfuess, K. E.: 1981, Forstwiss. Centralbl. 100,363.

Reiners, W. A. and Lang, G. E.: 1979, Ecol. 60,403.

Rennenberg, H., Kreutzer, K., Papen, H., Weber, P.: 1998, New Phytol. 139, 71.

Reuss, J. 0. and Johnson, D. W.: 1986, Acid Deposition and the Acidification of Streams and Waters. Springer-Veriag.

Richardson, C. T., Sasek, T. W., Fendick, E. A: 1992, Environ. Toxicol. Chem. 11, 1105.

Richter, D. D. and Markewitz, D.: 1995, pp. 315-336 in S. Fox and R A. Mickler (eds.), Impacts of Air Pollutants on Southern Pine. Springer-Verlag.

Richter, D. D., Markewitz, D., Wells, C. G., Allen, H. L., April, R, Heine, P. R., Urrego, B.: 1994, Ecology 75, 1463.

RMCC: 1990, The 1990 Canadian long-range transport of air pollutants and acid deposition assessment report: Part I Executive Summary. Federal-Provincial Research and Monitoring Coordinating Committee, Ottawa.

Robarge, W. P., Pye, J. M., Bruck, R I.: 1989, Plant and Soil 114, 19.

Robarge, W. P. and Johnson, D. W.: 1992, Advances in Agronomy 47,l.

Roberts, D. M. and Harmon, A. C.: 1992, Annu. Rev. Plant Physiol. Plant Mol. Biol. 43, 375.

Robitaille, G., Boutin, R, Lachance, D.: 1995, Can. J. For. Res., 25,577.

Roy, G., Robitaille, G., Gagnon, G.: 1985, Phytoprotection 66, 91.

Royle, D. D. and Lathrop R G.: 1997, For. Sci. 43,327.

Samuelson, L. J. and Kelly, I. M.: 1997, New Phytologist 136,255.

Sasek, T. W. and Flagler, R B.: 1995, Impacts or Air Pollutants on Southern Pine Forests. Springer-Verlag. pp. 424-466.

Sasek, T. W., Richardson, C. J., Fendick, E. A., Bevington, S. R, Kress, L. W.: 1991, For. Sci. 37, 1078.

Saxena, V. K., and Lin, N. H.: 1990, Atmos. Envir. 24A, 329.

Schaberg, P. G., Perkins, T. D., McNulty, S. G.: 1997, Can. J. For. Res. 27, 1622.

Schemenauer, R S.: 1986, Atmos. Ocean 24,303,

Scherbatskoy, T. de W.: 1989, Ionic Relations of Leaf Cuticles, Ph.D. Thesis, University of Vermont.

Schroeder, W. H., Bauch, J., Endeward, R: 1988, Trees 2, 96.

Schulze, E. D.: 1989, Science 244, 776.

Schulze, E. D., De Vries, W. Hauhs, M., Rosen, K., Rasmussen, L., Tamm, C. O., Nilsson J.: 1989, Water, Air, and Soil Pollut. 48,451.

Schulze, E. D., Robichaux, R H., Grace, J., Rundel, P. W., Ehleringer, J. R: 1987, Bioscience 37, 30.

Schutt, P. and Cowling, E. B.: 1985, The Amer. Phytopathological Soc. 69,

SCOPE: 1992, Effects of increased ultraviolet radiation on biological systems. Scientific Committee on Problems in the Environment, Paris.

Sheffield, R. M. and Cost, N. D.: 1987, J. For. 87, 29. 
Sheffield, R M. et al.: 1985, USDA For. Serv. Res. Bull. SE-83.

Shepard, M. R, Lee, C. E., Woosley, R S., Butcher, D. J.: 1995, MicrochemicalJ. 52,118.

Shortle, W. C. and Bondietti, E. A.: 1992, Water, Air, and Soil Pollut. 61,253.

Shortle, W. C., Smith, K. T., Minocha, R, Alexeyev, V. A.: 1995, J. Biogeography 22, 467.

Shortle, W. C. and Smith, K. T.: 1988, Science 240, 1017.

Shriner, D. S., Heck, W. W., McLaughlin, S. B., Johnson, D. W., Peterson, C. E.: 1990, NAPAP State of Science and Technology, National Acidic Precipitation Assessment Program.

Skarby, L., Troeng, E., Bostrom, C. A.: 1987, For. Sci. 33,801.

Skarby, L., Ro-Poulsen, H., Wellburn, F.A.M., Sheppard, L. J.: 1998, New Phytol. 139, 109.

Smith, W., and Mangold, R: 1996, Estimating status and change in forest health, U.S. Dep. Agric. Forest Service Fact Sheet.

Smith, G. F., and Nicholas, N. S.: 1999, Castanea (in press).

Stark, R. W.: 1965, Аnnu. Rev. Entomol. 10,303.

Sterba, H.: 1996, Forest decline and growth trends in Central Europe - a review. Berlin: Springer-Verlag.

Stienen, H. and Bauch, J.: 1988, Plant and Soil 106,231.

Stohlgren, T. J. and Parsons, D. J.: 1987, Atmos. Environ. 21, 1969.

Stow, T. K., Allen, H. L., Kress, L. W.: 1992, For. Sci. 38, 102.

Stoyenhoff, J., Witter, J., Leutscher, B.: 1998, Forest Health in the New England States and New York, University of Michigan, $31 \mathrm{pp}$.

Swank, W. T. and Vose, J. M.: 1997, Global Biogeochemical Cycles 11,657.

Taylor, G. E.: 1994, J. Environ. Qual. 23, 63.

Teskey, R 0.: 1995, pp. 467-490 in S. Fox and R A. Mickler (eds.), Impacts of Air Pollutants on Southern Pine. Springer-Verlag.

Teskey, R. O., Dougherty, P. M., Mickler, R. A.: 1998, pp. 279-290 in R A. Mickler and S. Fox (eds.), The Productivity and Sustainability of Southern Forest Ecosystems in a Changing Environment. Springer-Verlag.

Thomson, D. J.: 1995, Science 268, 59.

Timmel, T.E. 1996. pp 1907-1969 in Compression Wood Vo13. Springer-Verlag.

Tingey, D. T. and Hogsett, W. E.: 1985, Plant Physiol. 77,944.

Trewavas, A. J. and Malho, R: 1997, The Plant Cell 9, 1181.

Uhich, B.: 1984, Atmos. Env. 18,621.

Uhich, B. and Matzner, E.: 1986, Experientia 42,344.

USDA,: 1997, Forest Insect and Disease Conditions in the United States 1996. Forest Service Health Production, Washington, D.C., 87 p.

USDA Forest Service: 1996, Sampling and plot design, Forest health monitoring fact sheet 1909.14, USDA Forest Service, Washington, DC.

Vann, D. R., Strimback, G. R., Johnson, A. H.: 1992, For. Ecol. Manag. 51(1-3), 69.

Wallin, G. and Skarby, L.: 1992, Trees 6, 128.

Wargo, P. M.: 1972, Phytopathology 62, 1278.

Waring, G. L. and Cobb, N. S.: 1992, Insect-Plant Interactions. pp. 167-226.

Waring, R. H.: 1987, Bioscience 37,569.

Waring, R. H. and Pitman: 1985, Ecol. 66,889.

Watmough, S. A.: 1997, Envir. Rev. 5, 181. 
Watson, R T., Zinyowera, M. C., Moss, R H., Dokken, D. J.: 1998, The Regional Impacts of Climate Change, An Assessment of Vulnerability. Cambridge University Press.

Weeks, M. W., and Smoronok, D.: 1993, Aerial assessment of red spruce and balsam fir conditions in the Adirondack region of New York, etc. USDA-USFS Technical Report NA-TP-16-93, $141 \mathrm{p}$.

Wesselink, L. G., Meiwes, K. J., Matzner, E., Stein, A.: 1995, Environ. Sci. Technol. 29, 51.

Wessman, C. A., Aber, J. D., Peterson, D. L.: 1989, Int. J. Remote Sensing 10, 1293.

Wisiniewski, J.: 1982, Water, Air, Soil Pollut., 17, 361.

Witlcowski, Z., Madziara-Borusiewicz, K., Plonka, P., Zurek, Z.: 1987, Ekologia Polska 35, 465.

Wullschleger, S. D., Norby, R J., Gunderson C. A.: 1997, pp. 79-100 in L. H. Allen; Advances in Carbon Dioxide Effects Research. ASA Special Publication Nd'irh, X., Foster, N. W. and Arp, P. A.: 1993, Can. J. For. Res., 23,617.

Yin, X., Foster, N. W., Morrison, I. K., Arp, P.A.: 1994, Can. J. For. Res., 24, 1567.

Yoder, B. J., Ryan, M. G., Waring, R H., Schoettle, A. W., Kaufmann, M. R: 1994, For. Sci. 40,513 .

Zahner, R., Saucier, J. R. and Myers, R. K.: 1989, Can. J. For. Res. 19:612.

Zhao, X. J., Sucoff, E., Stadelmann, E. J.: 1987, Plant Physiol. 83, 159.

Zoettl, H. W. and Huettl, R. F.: 1986, Water, Air, and Soil Pollut. 31,449.

Acknowledgements

The authors wish to express their sincere appreciation to Dr. R Vet, Atmospheric Environment Service, Environment Canada, Downsview, Ontario and to Dr. T. Dann, Environmental Protection Service, Environment Canada, Ottawa, Ontario for calculation and mapping of $\mathbf{S O}_{4}, \mathrm{NO}, \mathrm{H}$ ion depositions and cumulative $\mathrm{O}_{3}$ sums. The senior author thanks the U.S. Forest Service for support of some aspects of his basic research reported herein and the Department of Energy, Bioenergy Feedstock Development Program at Oak Ridge National Laboratory for partial support of synthesis activities. This manuscript is Publication No. 4892 of the Environmental Sciences Division, Oak Ridge National Laboratory. ORNL is operated by Lockheed Martin Energy Research for the U.S. Department of Energy under contract No. DE-ACO5-960R22464. 